OECDpublishing

\title{
SUSTAINABLY FINANCING
}

INFRASTRUCTURE IN

SUB-SAHARAN AFRICA -

WHAT ROLE FOR THE

DEVELOPMENT ASSISTANCE COMMITTEE?

OECD DEVELOPMENT POLICY PAPERS

February 2021 No. 36 


\section{OECD Policy Paper}

This paper is published under the responsibility of the Secretary-General of the OECD. The opinions expressed and arguments employed do not necessarily represent the official views of the OECD member countries.

This document, as well as any data and any map include herein, are without prejudice to the status of or sovereignty over any territory, to the delimitation of international frontiers and boundaries and to the name of any territory, city or area. The document was authorised for publication by Jorge Moreira da Silva, Director of the Development Co-operation Directorate.

Please cite this paper as OECD (2021), "Sustainably financing infrastructure in Sub-Saharan Africa - What role for the Development Assistance Committee?" OECD Policy Papers 36, OECD Publishing Paris. 


\section{Abstract}

In a climate of heightened debt vulnerabilities, countries in sub-Saharan Africa struggle to fill the gap in infrastructure finance, which is paramount to achieving their sustainable development objectives. At the same time, the infrastructure financing landscape in the region has become increasingly diverse and challenging to navigate. This paper reviews the role of Development Assistance Committee (DAC) members in supporting countries to address mounting infrastructure needs while avoiding and mitigating potential debt crises.

The first part of the paper provides an overview of the infrastructure needs in sub-Saharan Africa. The second part presents the changes in infrastructure financing, highlighting the dominant roles of domestic government and non-DAC lenders. The third part explains how infrastructure finance can be a potential driver for the debt build-up in the region; but that the quality of spending and the diversity of financing providers can be mitigating factors. The fourth part includes policy recommendations for DAC members. 


\section{Foreword}

As part of a wider series of papers which explore the financing landscape in specific sectoral contexts, this paper examines how infrastructure in sub-Saharan Africa is financed. In line with the 2017 Development Assistance Committee (DAC) High Level Communiqué, which emphasised the need to "better understand the broad catalytic effect of official support and other resources by understanding the interlinkages among official development assistance (ODA), partner countries' domestic resources, private investment, remittances, philanthropy, trade finance and export credits, and other sources of finance", this paper examines the role of official development finance and how it compares to and interacts with other sources of financing in the region and in the sector.

Several considerations have guided the choice of the sector and region.

- Infrastructure is essential to the achievement of the 2030 Agenda. Interlinked with industrialisation and innovation, infrastructure is an SDG itself (SDG 9), but is also essential for achieving other SDGs. Access to quality infrastructure is critical for the reduction of poverty and inequality as well as for the fight against climate change and to the reversal of biodiversity declines.

- Infrastructure needs are especially pressing in sub-Saharan Africa (SSA), where countries lag considerably behind other regions in terms of the quantity, quality and accessibility of infrastructure. Despite significant increases in infrastructure finance to the region, current investment levels fall alarmingly short of growing needs, especially considering demographic and economic developments in the region

- However, the surge in infrastructure investment in the 2000s, combined with growing debt sustainability concerns, could cause hesitation among DAC members leading them to a more cautious approach in engaging in infrastructure finance in SSA. Debt levels have increased continuously, from $38.5 \%$ in 2010 to $55.9 \%$ in 2017 . The COVID-19 crisis has put debt sustainability considerations at the centre of development considerations in the region. As of June 2020, SSA government debt burdens had risen at a faster pace and to a higher level than for other emerging markets: heightening the risk of defaults.

It is a critical time to review the role of DAC members in the infrastructure financing landscape of SSA that has become increasingly diverse and complex. Can DAC members make a distinct contribution in this crowded space? How can the need for infrastructure finance be balanced with debt sustainability concerns? What can DAC members do to help prevent and mitigate debt crises rather than amplify its risks? How can DAC members become a part of a solution to the debt problem rather than part of it? 


\section{Acknowledgements}

The paper has benefited from the insightful comments and suggestion from many colleagues including: Lucila Arboleya Sarazola (International Energy Agency), Roland Kpodar, Daniel Gurara (International Monetary Fund) and reviewers from the IMF's African Department.

The authors would also like to thank the following collagues from the OECD's Development Co-operation Directorate who have provided helpful comments: Valentina Bellesi, Faty Dembele, Kaori Miyamoto, Paul Horrocks and Özlem Taskin. Shashwat Koirala has provided valuable support for the preparation and preliminary analysis of the data used in this paper. 


\section{Table of contents}

Foreword $\quad 4$

Acknowledgements $\quad 5$

Executive summary 8

1. Infrastructure is a critical enabler for sustainable development $\quad 10$

1.1. The infrastructure financing needs are especially pronounced in sub-Saharan Africa 11

1.2. Filling the infrastructure gap can conflict with debt sustainability concerns 13

2. Financing infrastructure - different actors and their contributions 15

2.1. Domestic finance is the dominant source of infrastructure finance 15

2.2. The composition of external finance for infrastructure has changed with debt raised from Chinese lenders gaining most ground $\quad 19$

2.3. While other actors are targeting increasingly similar destinations, DAC providers have a comparative advantage in low-income countries and the water sector 23

3. Key policy issues - reconciling debt sustainability with infrastructure financing $\quad 29$

3.1. The availability of more infrastructure finance can raise debt sustainability concerns 29

3.2. But the quality of spending matters more 34

3.3. The importance of quality investments are increasingly recognised by providers of
infrastructure finance

4. Policy implications of DAC members' role in sub-Saharan African infrastructure finance $\quad 40$

4.1. Why the DAC should care $\quad 40$

4.2. What the Development Assistance Committee can do 41

References $\quad 45$

$\begin{array}{ll}\text { Annex A. Methodological annex } & 49\end{array}$

A.1 Data sources and limitations 49

A.2 Methodological note for construction of index in Figure 1.2 and Figure $1.3 \quad 50$ 
Tables

Table 2.1. Different actors focus on different sub-sectors

Table A.1. Summary of indicators by dimension and subsector 50

\section{Figures}

Figure 1.1. Sub-Saharan Africa's infrastructure performance lags behind 11

Figure 1.2. The performance of infrastructure varies by region in sub-Saharan Africa 12

Figure 1.3. To fill the infrastructure gap, countries in sub-Saharan Africa need to invest a greater share of their GDP than other regions

Figure 2.1. Public investment grew until recently but has started to decline 16

Figure 2.2. Tax revenues have grown in recent years but not always as much as public investment 17

Figure 2.3. Official development assistance to domestic resource mobilisation does not always target

countries with the greatest needs $\quad 18$

Figure 2.4. Regardless of the source, external finance for infrastructure in sub-Saharan Africa has increased 20

Figure 2.5. The relative contribution of actors has changed, with China playing a greater role 21

Figure 2.6. Among DAC providers, the United States has entered a landscape previously dominated by

European and Japanese flows

Figure 2.7. Multilateral providers and China target increasingly similar destination countries

Figure 2.8. Official flows from DAC providers is mostly ODA and often takes the form of grants 24

Figure 2.9. The increase in energy-related bilateral flows from the DAC are partly driven by renewables 26

Figure 2.10. DAC providers are relatively influential in the neediest places 28

Figure 3.1. Debt vulnerabilities make it difficult for countries to invest more in infrastructure 29

Figure 3.2. Debt is used to finance infrastructure investments 30

Figure 3.3. Most permanent members of the Paris Club are in the DAC 33

Figure 3.4. Next to multilaterals non-Paris Club members and commercial lenders have become important creditors

Figure 3.5. More sub-Saharan African countries saw an increase in government consumption than in investment

Figure 3.6. Sub-Saharan Africa countries face the largest public investment efficiency gap

Figure 3.7. The five pillars of the OECD Sustainable Infrastructure Policy Initiative

Figure 3.8. Official development finance does not target countries with higher public sector efficiency in sub-

Saharan Africa

Figure 3.9. Countries with higher public sector efficiency receive more development finance for infrastructure

\section{Boxes}

Box 1.1. What is the Highly Indebted Poor Countries (HIPC) Initiative?

Box 2.1. Domestic resource mobilisation still leaves room for improvement in sub-Saharan Africa 18

Box 2.2. Lending with Chinese characteristics and its implications for debt sustainability in borrowing countries 22

Box 2.3. What is behind the energy drive in sub-Saharan Africa? $\quad 27$

Box 3.1. Debt restructuring in light of the COVID-19 crisis 32

Box 3.2. Emerging creditors with non-traditional financing practices intensify debt sustainability concerns 33

Box 3.3. OECD's Sustainable Infrastructure Policy Initiative $\quad 38$

Box 4.1. Recent initiatives on debt sustainability $\quad 44$ 


\section{Executive summary}

\section{Profound changes in the infrastructure financing landscape, both on the supply and demand side, complicate financing decisions for sub-Saharan African governments and for supporting actors.}

On the supply side, the rise of non-Development Assistance Committee (DAC) lenders, most prominently the People's Republic of China ("China"), has deeply changed the composition of external funds available for infrastructure investments. In 2018, China provided about $40 \%$ of external financing for the African continent, according to the International Consortium for Infrastructure (ICA). Due to some specificities of Chinese funds, this can cause challenges in the monitoring and management of debt.

Sub-Saharan African countries, who are on the demand side of infrastructure finance, have undergone changes too. Among 49 SSA countries, 20 have seen their income category reclassified since 2000: from low-income to lower middle-income, or from middle-income to upper middle-income country status. Prior to the COVID-19 crisis, the region had a solid growth rate of $2.3 \%$ in 2019 , boosted by a positive outlook for regional trade integration. Moreover, with the highest rates of population growth in the world $(2.7 \%)$ compared to $1.2 \%$ in South Asia and $0.9 \%$ in Latin America, the population is likely to double by 2050 (World Bank, 2020[1]).

As a consequence, commercial borrowing and non-concessional conditions, both international and domestic issued to local commercial banks represent an increasing share of government liabilities (Coulibaly, Gandhi and Senbet, 2019 $\left.{ }_{[2]}\right)$. As a result, borrowing costs increased, further limiting governments' room for manoeuvre and challenging their ability to prudently manage debt.

These changes heighten debt sustainability concerns, possibly causing reluctance among DAC providers to invest in infrastructure in sub-Saharan Africa. The experience of debt crises in SSA is still fresh for members of the DAC. Growing concerns about debt sustainability in SSA could lead to further withdrawal of the DAC as a provider of infrastructure finance.

However, providing continued support for more and more sustainable infrastructure finance is key to achieving the DAC's mandate and supporting the SDGs. DAC providers still play a special role in sub-Saharan infrastructure finance, which cannot be easily filled by other actors. While the latter are increasingly moving towards the energy and transport sectors in middle-income countries, DAC providers retain a strong comparative advantage in water infrastructure, and emphasise infrastructure finance in lowincome countries (LICs), a group that includes 24 of the 49 countries in sub-Saharan Africa. As a guardian of development co-operation principles, the DAC can also help ensure that infrastructure investments are sufficiently aligned with sustainable development considerations.

The DAC's withdrawal from infrastructure financing could contribute to a worsening rather than improvement of the debt situation in SSA. With reduced access to concessional sources of finance for infrastructure investments, SSA countries will increasingly rely on more expensive financing such as capital market debt. Moreover, the presence of DAC providers as alternative financiers can increase SSA governments' leverage in negotiating the terms of the financing from other providers. Anecdotal evidence 
suggests that countries who restructure loans from the China could negotiate more lenient terms if they had access to a diversified creditor base (Kratz, Feng and Wright, 2019 $\left.9_{[3]}\right)$. However, scarce concessional resources should be used in a way to complement and promote other sources of finance including private sector lending.

\section{Some of the below points can guide DAC providers' response to the changing infrastructure financing landscape in the region:}

- Building on core strengths and comparative advantages

- Groups of countries and sub-sectors (e.g. water, LICs), in which DAC members have a comparative advantage, need continued and targeted support.

- DAC donors can further champion and support politically less favourable projects, which nevertheless have the potential for high economic returns (e.g. maintenance projects).

- The DAC can support standard-setting related to infrastructure finance, e.g. through involvement in the OECD's Sustainable Infrastructure Policy Initiative, which is led by the Directorate for Financial and Enterprise Affairs. The DAC can also encourage other providers of development co-operation to adhere more closely to international standards and practices, to improve transparency and accountability in the development co-operation globally.

- Investing in better quality public spending and debt management to minimise debt sustainability risks

- DAC providers can strengthen support for public investment management, especially in the form of technical assistance for downstream capacities such as project selection and management.

- In parallel, DAC members can continue to build on existing efforts to incentivise public investment efficiency in SSA by allocating more infrastructure finance to countries with better results.

- Moreover, DAC donors can provide technical assistance and capacity building, supporting developing countries gain access to certain funds (e.g. climate finance), identify best partners and instruments, and negotiate the best terms and conditions with them.

- Providing upstream support such as policy and regulatory reform

- DAC members can also support upstream measures such as policy and regulatory reform by incentivising and promoting the integration of economic, social and environmental sustainability considerations in the design and implementation of infrastructure projects. 


\section{Infrastructure is a critical enabler for sustainable development}

Infrastructure ${ }^{1}$ forms the backbone of society and has a cross-cutting relevance to the achievement of Sustainable Development Goals (SDGs). Recent estimates suggest that infrastructure is either directly or indirectly related to all other SDGs, including $72 \%$ of the targets (Thacker et al., 2019 $9_{[4]}$ ).

Interlinked with industrialisation and innovation, infrastructure is an SDG itself (SDG 9), but is also essential for achieving socio-economic SDGs. Infrastructure can promote the achievement of inclusive growth (Goal 8 ) and the reduction of inequality (Goal 10). Hjort and Poulsen (2019 $\left.{ }_{[5]}\right)$ show that the arrival of high-speed internet in sub-Saharan Africa increased employment, firm entry and productivity, especially for higherskilled workers.

Great progress was made towards most of the health-related Millennium Development Goals, notably Goals 4 (reduce child mortality), 5 (improve maternal health) and 6 (combat HIV/AIDS, malaria and other diseases).

- Globally, the number of deaths of children under five years of age fell from 12.7 million in 1990 to 5.3 million in 2018. The under-five mortality rate declined from 93 per 1000 live births in 1990 to 39 per 1000 live births in 2018 (WHO, 2020[6]).

- In low- and middle-income countries, the percentage of underweight children under five years old dropped from about 28\% in 1990 to $15 \%$ in 2017 (World Bank, 2020[1]).

- Globally, new HIV infections fell by $37 \%$ between 2000 and 2018 while HIV-related deaths declined by $45 \%\left(\mathrm{WHO}, 2019_{[7]}\right)$.

By enhancing access to basic services, infrastructure helps to address poverty (Goal 1), reduce hunger (Goal 2), attain good health and well-being (Goal 3), provide quality education (Goal 4), supply clean water and sanitation (Goal 6), and combat climate change and its impacts. For example, access to energy is central for better education, as is access to clean water and sanitation for better health. These services are also critical for gender equality (Goal 5$)$. Dinkelman $\left(2011_{[8]}\right)$ shows that rural electrification programmes have an impact on employment, especially female employment, as households with access to electricity can free up time spent on cooking and lighting and devote more time to self-employment or microenterprises.

\footnotetext{
${ }^{1}$ Building on the previous work of the OECD Development Assistance Committee (DAC) on infrastructure financing, this paper, refers to infrastructure as sectors 140 (Water \& Sanitation), 210 (Transport \& Storage), 220 (Communications), and 230 (Energy Generation and Supply) in the Creditor Reporting System (CRS).
} 


\subsection{The infrastructure financing needs are especially pronounced in sub- Saharan Africa}

On every measure of infrastructure, SSA countries are lagging behind peer countries in other regions, with Central Africa facing the largest gap.

Countries in sub-Saharan Africa (SSA) considerably lag behind other regions in terms of the infrastructure performance. Figure 1.1 demonstrates the disparity in infrastructure development between development finance recipients in sub-Saharan Africa and those in the rest of ODA-eligible countries. Based on Calderón, Cantú and Chuhan-Pole (2018[9]), this figure decomposes infrastructure development into three dimensions of access, quality, and quantity, with relevant indicators for each dimension informing performance.

Figure 1.1. Sub-Saharan Africa's infrastructure performance lags behind

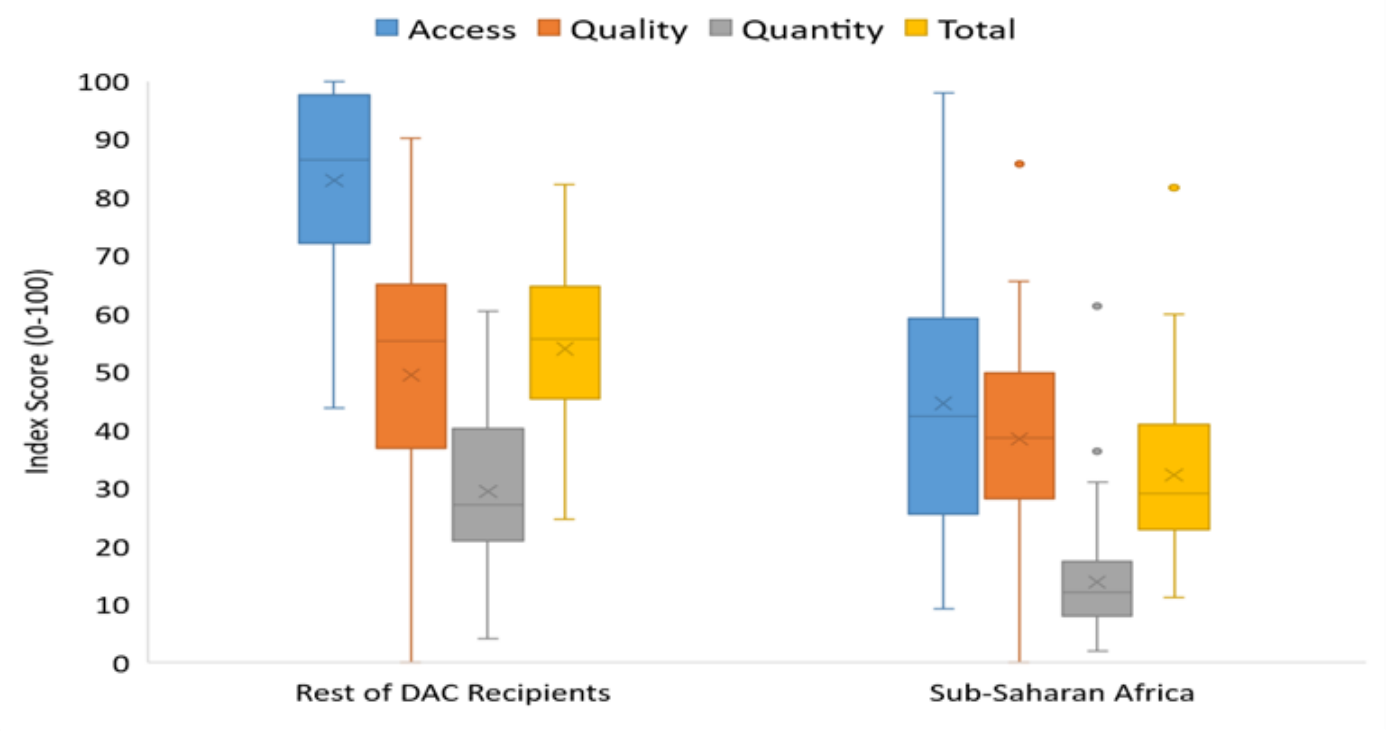

Note: More detailed explanations about how the index is constructed are in the Annex.

Source: Authors' calculations based on ITU (2019[10]) World Telecommunication/ICT Indicators database (https://www.itu.int/en/lTUD/Statistics/Pages/stat/default.aspx); World Bank (World Bank, 2020[1]), World Development Indicators database, http://datatopics.worldbank.org/world-development-indicators/; WEF (2017-2018[11]), Global Competitiveness Report, http://reports.weforum.org/pdf/gci-2017-2018-scorecard/WEF_GCI_2017_2018_Scorecard_EOSQ057.pdf.

A regional breakdown of the index values reveals that overall, the needs seem to be most pressing in Central Africa, which has the lowest average composite value for the index. This is due to particularly low scores for quality and quantity.

West Africa has the second lowest composite index value, with poor results for quality but relatively high results for access.

East Africa has comparatively high-quality infrastructure but the lowest average value for access, with a wide variation between countries. East Africa is also performing poorly in terms of quantity.

Southern Africa is the best-performing region overall, but this masks a wide variation between countries in terms of access and quality. 
Figure 1.2. The performance of infrastructure varies by region in sub-Saharan Africa

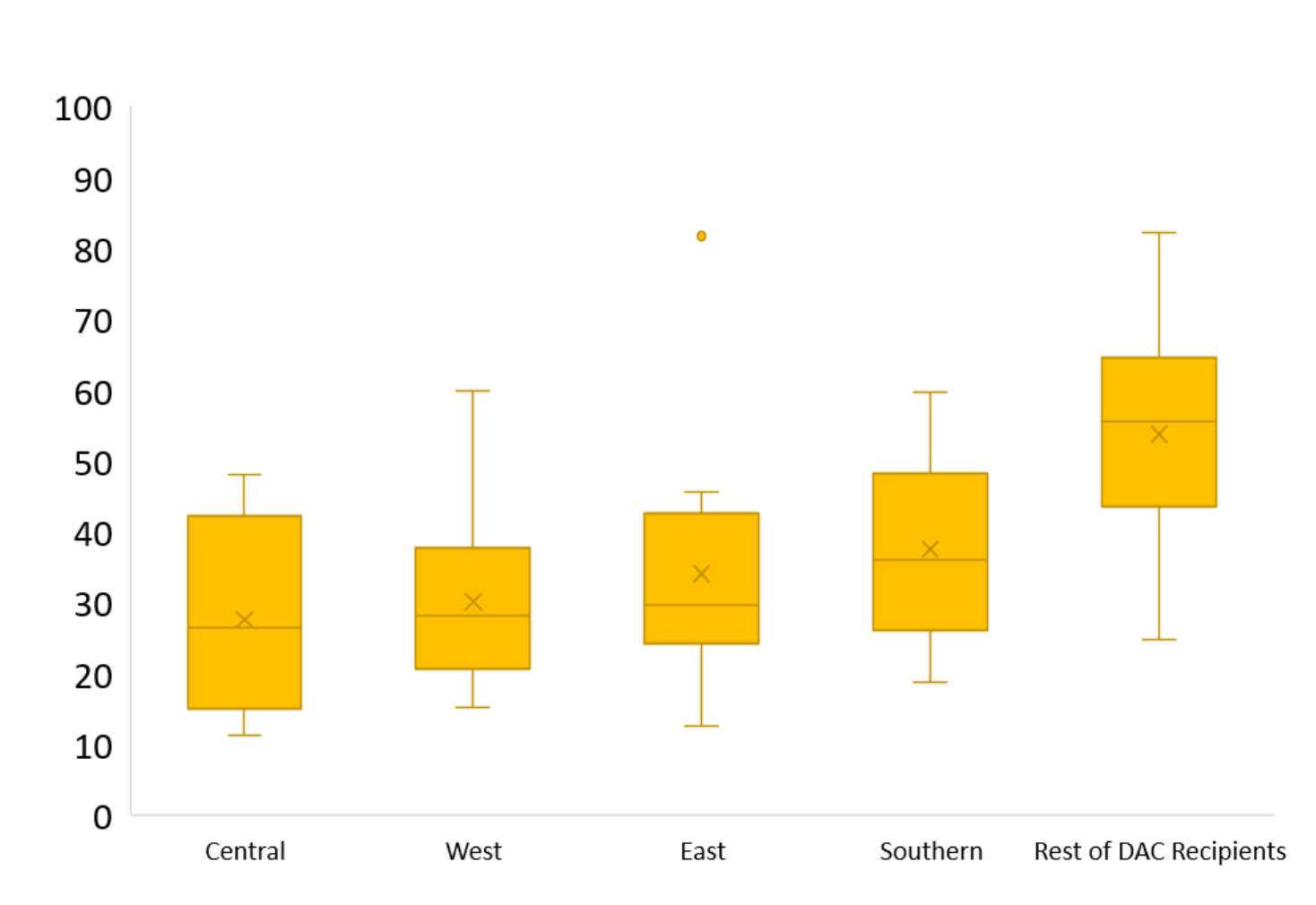

Note: More detailed explanations about how the index in constructed are in the annex.

Source: Authors' calculations based on ITU $\left(2019_{[10]}\right)$ World Telecommunication/ICT Indicators database (https://www.itu.int/en/ITUD/Statistics/Pages/stat/default.aspx); World Bank (World Bank, 2020[1]), World Development Indicators database, http://datatopics.worldbank.org/world-development-indicators/; WEF (2017-2018[11]), Global Competitiveness Report, http://reports.weforum.org/pdf/gci-2017-2018-scorecard/WEF_GCl_2017_2018_Scorecard_EOSQ057.pdf.

Sub-Saharan Africa is the region with the greatest infrastructure financing needs in the world. According to recent estimates, the baseline scenario infrastructure financing needs for sub-Saharan Africa are estimated to reach $9.2 \%$ of GDP in total $(7.2 \%$ for capital investments and another $2 \%$ for maintenance.) This compares to $7.5 \%$ in South Asia, $7.2 \%$ in the Middle East and North Africa, $6.5 \%$ in East Asia and Pacific, and 4.5\% in Latin America and the Caribbean (Rozenberg and Fay, 2019[12]). 
Figure 1.3. To fill the infrastructure gap, countries in sub-Saharan Africa need to invest a greater share of their GDP than other regions

$\%$ of GDP

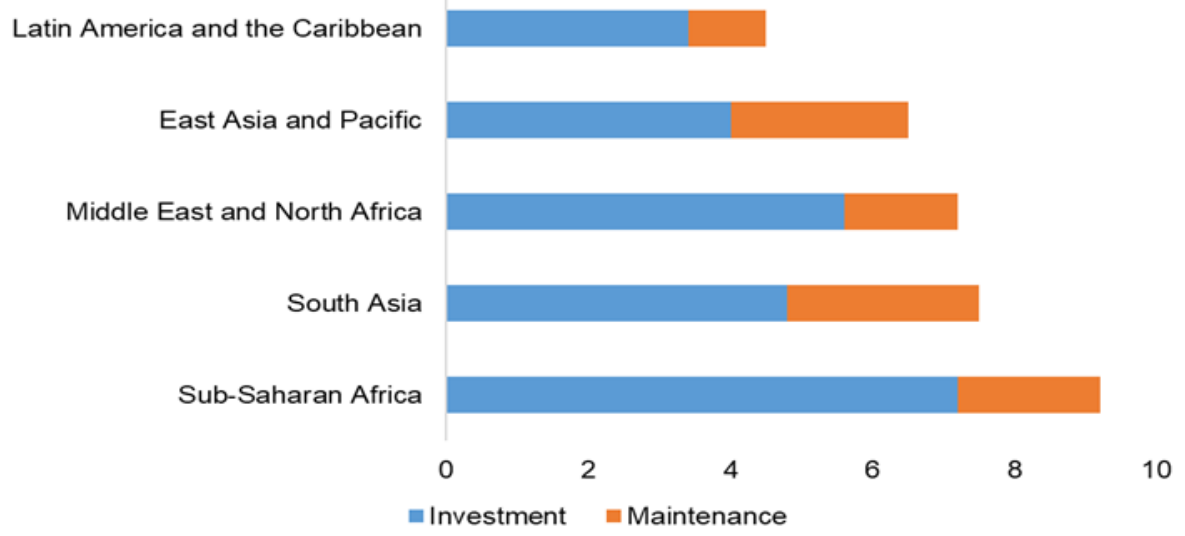

Source: Authors 'illustration based on Rozenberg and Fay, (2019[12]), "Beyond the Gap: How Countries Can Afford the Infrastructure They Need while Protecting the Planet. Sustainable Infrastructure", https://openknowledge.worldbank.org/handle/10986/31291.

Despite an overall increase, infrastructure finance still falls short of needs. According to the Infrastructure Consortium for Africa (ICA), about USD 100.8 billion of commitments in infrastructure finance were made in 2018 for Africa including Northern Africa, up from USD 81.6 billion in 2017 and USD 66.9 billion in 2016. The commitments made to sub-Saharan Africa amounted to USD 80.7 billion. (ICA, 2019 $\left.{ }_{[13]}\right)$ This amount of USD 80.7 billion infrastructure finance available to SSA translate into $4.7 \%$ of GDP, significantly below the estimated $7.2 \%$ of GDP in capital investment needs that have been referred to above (Rozenberg and Fay, 2019 $[12])$.

\subsection{Filling the infrastructure gap can conflict with debt sustainability concerns}

Infrastructure spending has risen worldwide since the 2000 s including in sub-Saharan Africa. This investment surge was concomitant with major successes in economic stabilisation and progress for economic growth in Africa. In particular, the significant reduction in debt levels of SSA countries through major relief initiatives such as the HIPC initiative provided breathing room for governments to invest again (Box 1.1). Between 2000 and 2008, gross government debt fell from $67 \%$ of regional GDP to $28 \%$. In the meantime, per capita GDP growth accelerated, from an average of $0.6 \%$ per year between 1995 and 2000 to $3 \%$ ten years later, and investment also increased (IMF, 2020[14]).

However, the infrastructure boom gave way to more caution - especially due to growing debt sustainability concerns. By the mid-2010s a variety of factors, among which the slowdown in global growth, the end of the commodity super-cycle, a return of political instability and civil conflicts tempered the optimism of the 2000s. Debt sustainability concerns intensified, together with the realisation that infrastructure investments would not continue without problems. Overall, debt levels as a share of GDP have increased since 2011 (IMF, 2020[14]). On average, gross government debt as a percentage of GDP in SSA, rose from $38.5 \%$ in 2010 to $55.9 \%$ in 2017. According to the IMF Debt Sustainability Assessments for Low-Income Countries, 5 countries in SSA are in debt distress. Another 13 SSA countries are at high risk of debt distress, against only 4 in 2014.

The COVID-19 crisis has put debt sustainability concerns at the centre of regional development considerations. Calls for debt relief have resulted in the Debt Service Suspension Initiative (DSSI) 
spearheaded by the G20, providing a moratorium on debt payments from May to December 2020. As of end August 2020, 31 SSA countries have signed up for participation in the DSSI initiative.

Supply-side factors in both infrastructure provision and financing have also changed the nature of public debt. The rise of non-DAC lenders, most prominently China, has changed the composition of external debt. Chinese funds are the largest external source of infrastructure finance in the region, and the share has grown to close to $40 \%$ in the 2010 s up from below $30 \%$ in the early 2000 s. As will be explored in more detail, financing terms that are attached to loans from Chinese entities are often different from official flows from DAC providers, which can cause challenges in the monitoring and management of debt.

Adding to that are the challenges that come from the transition that SSA countries have undergone as they gained access to a wider set of financing options. Among 49 SSA countries, 20 countries have undergone a re-classification of the income category since 2000, from low-income to lower middle-income, or from middle-income to upper middle-income country status. As a consequence, commercial borrowing represents an increasing share of government liabilities (Coulibaly, Gandhi and Senbet, 2019 ${ }_{[2]}$ ). In many countries, borrowing costs increased, further limiting governments' room for manoeuvre.

Those elements have made the debt-infrastructure nexus a central question for development in sub-Saharan African countries, and should be central for the donor community:

\section{How to support poverty reduction in Africa, and SDG-oriented policies more broadly while limiting risks of financial unsustainability?}

This report proceeds in three parts. First, it highlights the changes in the financing of infrastructure in Africa in the past 15 years. It shows that financing has increased until about 2015, but started to stagnate in the past few years. Second, it explores the link between infrastructure investment and indebtedness. While new actors and financing sources have led to higher debt levels, this part also shows that the quality of investment management also matters. Finally, it offers policy recommendations to the DAC.

\section{Box 1.1. What is the Highly Indebted Poor Countries (HIPC) Initiative?}

Initiated by the International Monetary Fund and the World Bank in 1996, the HIPC initiative provides debt relief and low-interest loans to cancel or reduce external debt repayments to sustainable levels. To qualify for assistance, countries need to face an unsustainable debt burden, which cannot be managed with traditional debt relief mechanisms, and meet a range of economic management and performance targets aimed at reducing poverty and enhancing economic growth.

The HIPC initiative identified 39 countries to be potentially eligible for debt relief, among which 33 were sub-Saharan countries. As of 2019, 36 countries had received full or partial debt relief, while the three remaining countries, which are Eritrea, Somalia and Sudan, are considered for entry into the programme. The total cost of providing debt relief to the 39 countries is estimated to be about USD 77 billion in end-2015 net present value terms. The largest creditors including multilateral development banks and all Paris Club creditors have provided their full share of debt relief under the HIPC Initiative, and even beyond.

However, non-Paris Club official bilateral creditors, and commercial creditors, which together account for about $27 \%$ of total HIPC Initiative costs, have only delivered a small share of their expected relief. While non-Paris Club bilateral creditors as a whole have delivered around $47 \%$ of their share of HIPC Initiative debt relief, one third of these creditors have not delivered any relief at all.

Source: IMF, $\left(2019_{[15]}\right)$, Debt relief under the Heavily Indebted Poor Countries Initiative, https://www.imf.org/en/About/Factsheets/Sheets/2016/08/01/16/11/Debt-Relief-Under-the-Heavily-Indebted-Poor-Countries-Initiative 


\title{
2. Financing infrastructure - different actors and their contributions
}

\author{
The financing landscape in sub-Saharan Africa has undergone some profound changes since 2000, \\ experiencing a substantial increase in the availability of infrastructure finance.
}

On aggregate, about USD 100.8 billion of commitments in infrastructure were registered in 2018, according to the Infrastructure Consortium for Africa $\left(I C A, 2019_{[13]}\right)$. That outcome takes into account all sources: private, domestic public and external. It is the highest figure in years, after a stagnation since 2014.

Three facts characterise the financing of infrastructure in Africa:

Fact 1 - Most infrastructure investments are paid for by the domestic public sector, with an increasing portion financed through debt

Fact 2 - The composition of external finance for infrastructure has changed, with debt raised from Chinese lenders gaining most ground. This can have implications on the transparency and sustainability of debt.

Fact 3 - While other actors (i.e. multilateral providers and Chinese entities) are targeting increasingly similar destinations (i.e. lower middle-income countries, energy and transport sectors), DAC providers focus more on infrastructure finance in low-income countries and especially the water sector.

\subsection{Domestic finance is the dominant source of infrastructure finance}

Domestic governments account for the largest part of infrastructure finance. According to ICA data quoted above, domestic governments account for $37 \%$ of infrastructure finance commitments made in the Africa (including northern Africa). Although the detailed breakdown into domestic government and private and external sources is not available for sub-Saharan Africa, public investment trends in the region suggest that domestic governments provide a significant portion of infrastructure finance.

Public investment, which often serves as a proxy for infrastructure investment, is twice to more than three times the amount of external resources provided for infrastructure finance in SSA. This implies that a significant portion of public infrastructure investments are financed by domestic sources. More detailed budget-level data indicate that there is some exaggeration in the public investment figures, as countries in SSA tend to underspend allocated budgets, but even these resources confirm that a considerable portion of investments are financed by domestic budgets. 
Figure 2.1. Public investment grew until recently but has started to decline

$\%$ of GDP

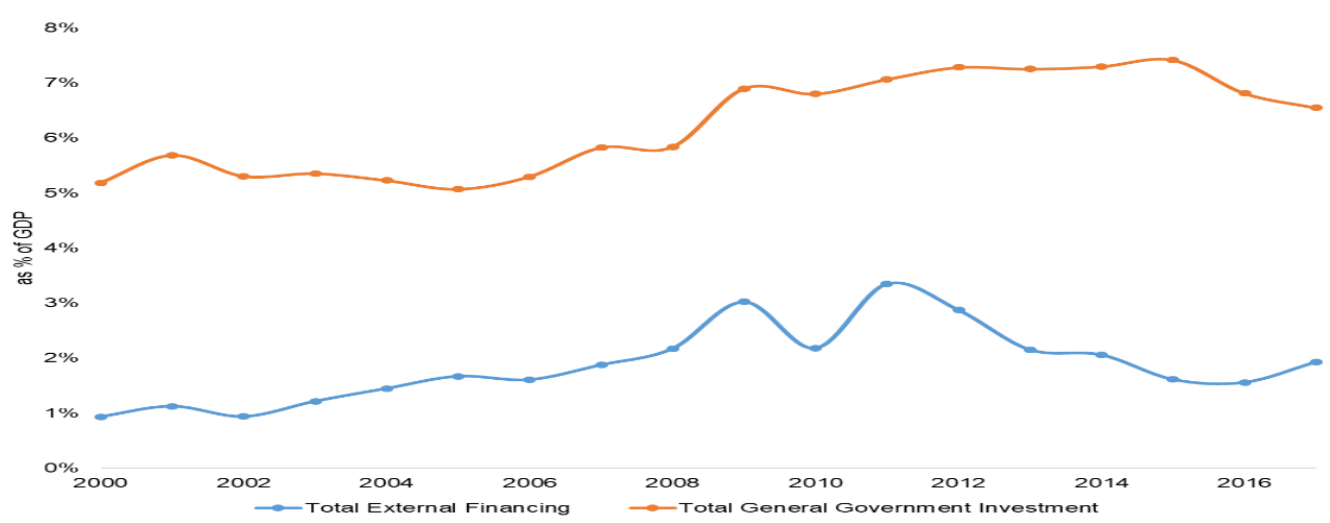

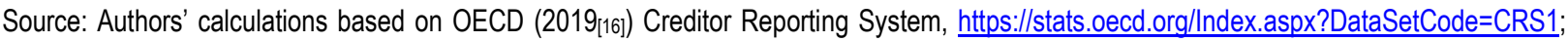
World Bank $\left(2019_{[17]}\right)$, Private Participation in Infrastructure (PPI) database, https://ppi.worldbank.org/en/ppidata; AidData (2017[18]), Global Chinese Official Finance database, https://www.aiddata.org/data/chinese-global-official-finance-dataset; International Monetary Fund (2017[19]), Investment and Capital Stock Dataset, https://www.imf.org/external/np/fad/publicinvestment/\#5.

However, after having increased steadily for an extended period, public investment levels have started to decline. This may have to do with the fact that governments in sub-Saharan Africa increasingly face limitations in expanding their public budgets, due to pressures within and outside of the infrastructure sector. For example, there is only limited scope to enhance tax revenues sufficiently to keep up with growing investment levels. In 14 of the 19 countries, for which tax data are available, tax revenues have increased. However, for a number of countries such as Zambia, investment has increased by far more than tax revenues. In Zimbabwe and Ethiopia, investment has increased despite a decline in tax revenues. 
Figure 2.2. Tax revenues have grown in recent years but not always as much as public investment 2011-2017

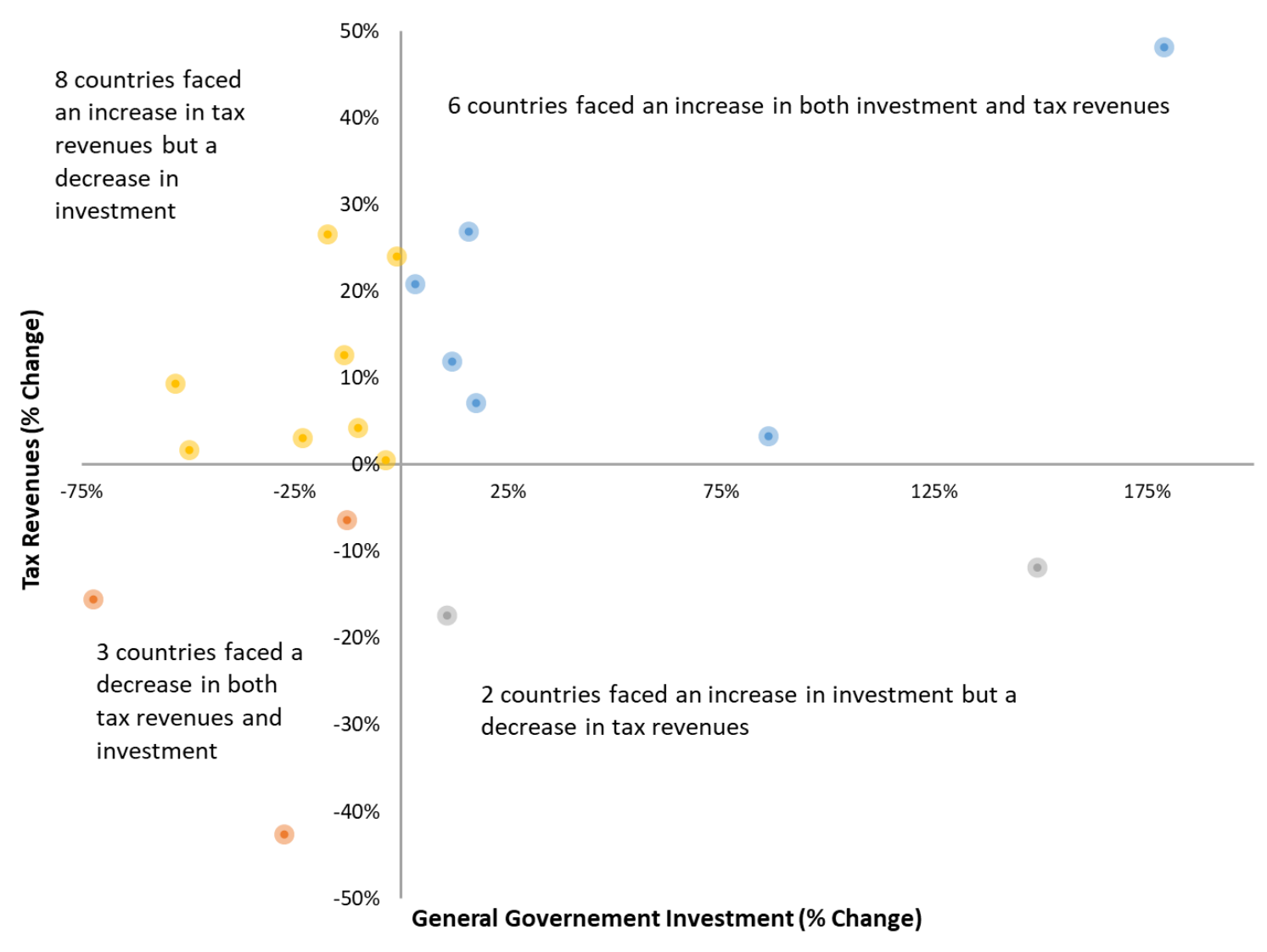

Note: The graph reports data for countries where both information on general government investment as well as tax revenues were available. The threshold that defines the two groups is given by the value of the median percentage change in public debt level.

Source: Authors' calculations based on International Monetary Fund $\left(2017_{[19]}\right)$, Investment and Capital Stock Dataset, https:/www.imf.org/external/np/fad/publicinvestment/\#5; World Bank (2020[1]), World Development Indicators database, https://databank.worldbank.org/source/world-development-indicators 


\section{Box 2.1. Domestic resource mobilisation still leaves room for improvement in sub-Saharan Africa}

Five years since the Addis Ababa Action Agenda recognised domestic public revenue as a key resource to finance sustainable development, there is still ample room to increase domestic resource mobilisation in SSA.

In 2017, the unweighted average tax-to-GDP ratio for 26 countries in Africa, for which tax data are available in OECD's Revenue Statistics Database, was $17.2 \%$ However, there is a wide variation in the level of tax-to-GDP ratios among countries, ranging from $5.7 \%$ in Nigeria to $31.5 \%$ in the Seychelles. Ten countries had a tax-to-GDP below $15 \%$, which is considered a minimum condition for effective state functioning (OECD/ATAF/AUC, 2019[20]).

Recent IMF research on the tax potential of SSA countries finds that in 20 out of the 38 countries covered, there is potential of over $1.5 \%$ of GDP to increase tax efficiency and raise revenues. The report also estimates that realising this potential in all 38 countries would represent increased revenue of between USD 50 billion and USD 80 billion per year (IMF, 2018[21])

DAC providers have scaled up their support for domestic resource mobilisation, but further efforts including better targeting are necessary for palpable results.

The Addis Tax Initiative (ATI) was a main driver behind the increase in ODA for domestic resource mobilisation (DRM). ATI members increased ODA disbursements in support of DRM from USD 61 million in 2014 to USD 358 million in 2016, a 482\% increase over the period. (Watts, 2018[22])

However, the overall increase in ODA for DRM masks considerable differences among countries. While some countries with a high tax gap and relatively low tax-to-GDP ratios received significant funding (e.g. Uganda, United Republic of Tanzania and Ghana), others such as Nigeria, the Republic of Congo, Madagascar and Cameroon received little or no support, despite low tax collections compared with economic output, and high tax gaps. (Watts, 2018[22])

\section{Figure 2.3. Official development assistance to domestic resource mobilisation does not always} target countries with the greatest needs

ODA to domestic resource mobilisation against tax-to-GDP ratio of receiving countries

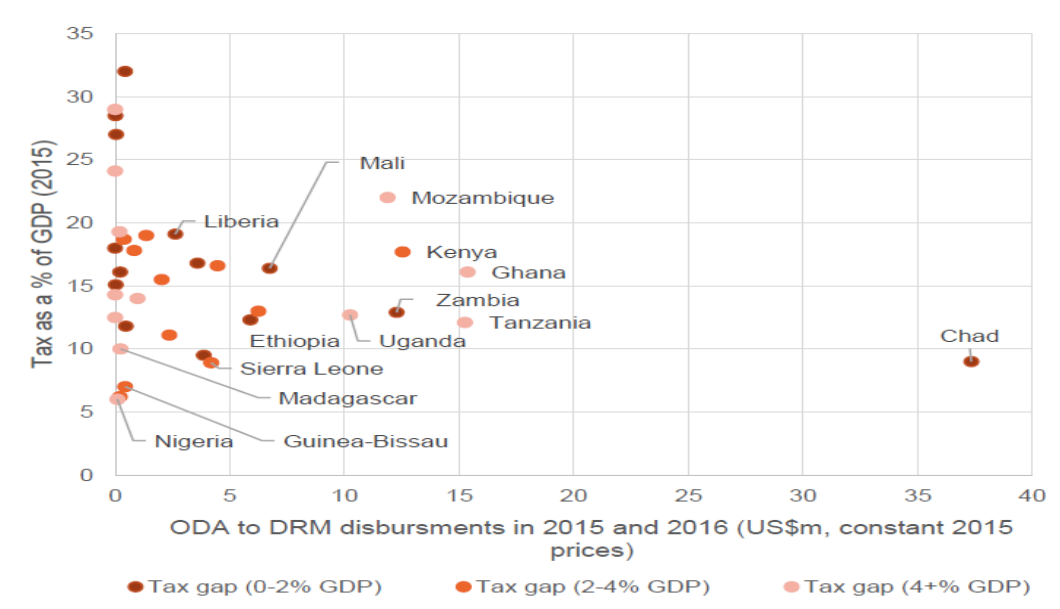

Source: Watts, (2018[22]), ODA for domestic revenue mobilisation: progress, prospects and opportunities for effective support, https://devinit.org/documents/49/ODA-for-domestic-revenue-mobilisation.pdf 
As a consequence, more and more investment spending needs to be financed by raising more debt. $^{2}$

More frequently than in the past, SSA countries find recourse to commercial debt in the form of sovereign bonds (see e.g., IMF 2019). As of end 2018, a total of 17 sub-Saharan African countries had outstanding Eurobonds, including Republic of the Congo, Senegal, Rwanda, Mozambique, Kenya and Zambia. In 2018 alone, Angola, Ghana, Côte d'Ivoire, Kenya, Nigeria, Senegal and South Africa each issued Eurobonds collectively amounting to USD 13.7 billion. In 2010, by comparison, no bonds were issued, while in 2001 bond receipts amounted to around USD 1 billion. (Velde, 2014[23])

Some countries also tapped local domestic lenders, which can then invest their liquidity, sometimes at the risk of crowding out private sector borrowers. For a sample of 31 SSA countries, Battaile et al. (2015[24]) find that domestic debt constituted on average about one-third of total public debt in 2013. In 11 of these countries, domestic creditors accounted for a minimum $40 \%$ of public debt. However, although domestic bond markets (or bank loans) reduce exchange rate risks, they are often more expensive and based on shorter maturities.

Heightened concerns around the region's debt sustainability call for a re-assessment of external finance for infrastructure investments in sub-Saharan Africa. Public debt levels in SSA substantially increased, from $38.5 \%$ in 2010 to $55.9 \%$ in 2017 , and reduced fiscal space for development spending. According to the IMF Debt Sustainability Assessments for Low-Income Countries, 5 countries in SSA are in debt distress. Another 13 SSA countries are at high risk of debt distress. ${ }^{3}$ In this climate, the availability of external financing resources devoted to infrastructure finance deserves renewed attention.

\subsection{The composition of external finance for infrastructure has changed with debt raised from Chinese lenders gaining most ground}

\section{External finance has increased in the 2000's regardless of the source, outpacing economic growth in the region.}

External finance includes public resources including official flows (official development assistance and other official flows) provided by DAC members and multilateral organisations, as well as non-DAC members such as Chinese public entities. It also includes private resources such as remittances, philanthropic flows, and commercial investments. The Annex includes more detailed information on the data used for this analysis.

External finance consisting of the various sources listed above grew from USD 3.3 billion in 2000 to USD 22 billion in 2014 , or by a compounded average of $15.6 \%$ per annum. This increase outpaced real GDP growth in the region, which on a compounded basis was $6.7 \%$ in the same period. ${ }^{4}$

\footnotetext{
2 This increase in public investment could come from three main sources: tax revenues, reduced spending in other categories (current expenditure) and borrowing.

${ }^{3}$ The countries in debt distress are: Republic of Congo, Mozambique, Somalia, Sudan and Zimbabwe. The countries at high risk of debt distress are: Burundi, Cameroon, Cabo Verde, Central African Republic, Chad, Ethiopia, Gambia, Ghana, Kenya, Mauritania, Sierra Leone, South Sudan and Zambia.

${ }^{4}$ Limited data availability especially on finance from China constrains the time from of this analysis to the period from 2000 to 2014 , for a comparative overview of different sources of finance. For official flows from multilateral and bilateral DAC and DAC-reporting providers, the analysis is extended to more recent years.
} 
Figure 2.4. Regardless of the source, external finance for infrastructure in sub-Saharan Africa has increased

2014 USD billion

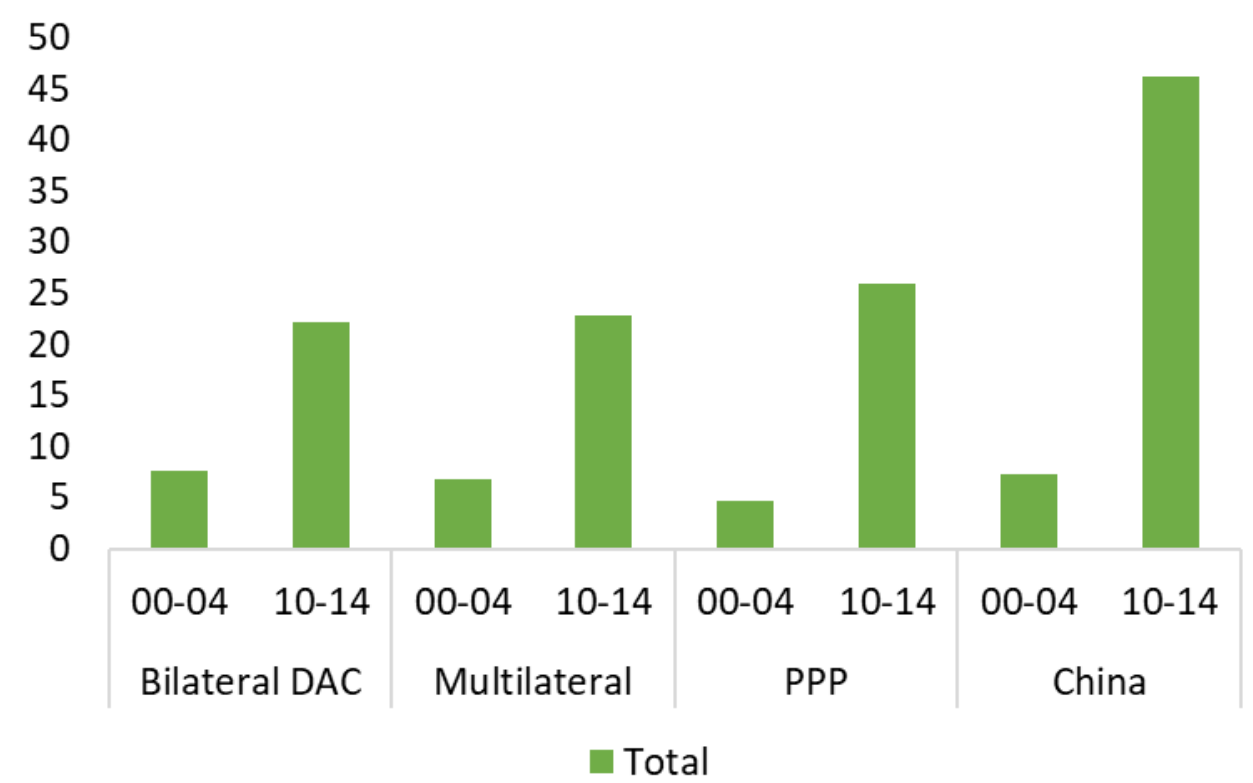

Note: See Annex A for caveats on the comparability across the data on the different sources.

Source: Authors' calculations based on Creditor Reporting System $\left(2019_{[16]}\right)$, https://stats.oecd.org/Index.aspx?DataSetCode=CRS1; World Bank (2019[17]), Private Participation in Infrastructure (PPI) database, https://ppi.worldbank.org/en/ppidata; AidData (2017[18]), Global Chinese Official Finance database, https://www.aiddata.org/data/chinese-global-official-finance-dataset

Between 2010 and 2014, Chinese infrastructure finance experienced the most prominent growth. Chinese infrastructure finance amounted to a cumulative 2014 USD 46.3 billion, more than six times the amount that was disbursed from 2000 to 2004 (USD 7.3 billion). Chinese funds are the largest source of external infrastructure finance, and the share is increasing having grown from $27.7 \%$ to $39.4 \%$.

The analysis is, of course, limited by the relative lack of transparency in existing data. In addition, as mentioned above, the data ${ }^{5}$ on infrastructure finance from China that are used in this analysis are only available until 2014. With the launch of the Belt-Road Initiative in 2013, the share of Chinese finance may have increased even more The estimate, though, is still in line with more recent ICA estimates of Africawide Chinese infrastructure finance, which account for $40 \%$ of all external infrastructure finance in 2018. (ICA, 2019 $\left.9_{[13]}\right)$ Averaging across different countries within SSA masks stark variation across countries. In some SSA countries, Chinese lending presents a significant portion of GDP, ranging from $9 \%$ in Equatorial Guinea and $20 \%$ in Zimbabwe to $100 \%$ in Djibouti (Horn, Reinhart and Trebesch, 2019[25]).

\footnotetext{
${ }^{5}$ AidData uses newspapers, expert inputs and other sources to define a database, as comprehensive as possible, of Chinese projects. However, the opacity and complexity of Chinese development finance explains that by design, those numbers are probably under-estimated (see more details in Box 2.1).
} 
Figure 2.5. The relative contribution of actors has changed, with China playing a greater role

Weight in total, cumulative over respective periods

\section{0-04}

- Bilateral DAC

- Multilateral

- PPP

$\square$ China

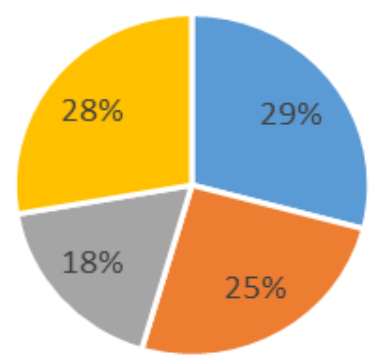

$10-14$

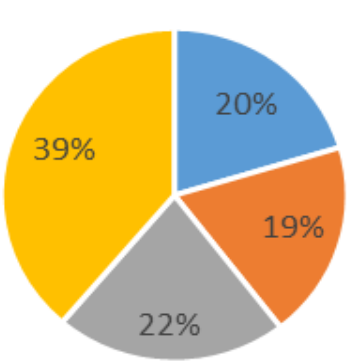

Note: See Annex A for caveats on the comparability across the data on the different sources.

Source: Authors' calculations based on Creditor Reporting System (2019 $\left.9_{[16]}\right)$, https://stats.oecd.org/lndex.aspx?DataSetCode=CRS1; World Bank $\left(2019_{[17]}\right)$, Private Participation in Infrastructure (PPI) database, https://ppi.worldbank.org/en/ppidata; AidData (2017[18]), Global Chinese Official Finance database, https://www.aiddata.org/data/chinese-global-official-finance-dataset

Due to several characteristics that distinguish Chinese financing patterns, this trend can present a challenge to ensuring the financial stability and debt sustainability in recipient countries (Box 2.2). 


\section{Box 2.2. Lending with Chinese characteristics and its implications for debt sustainability in borrowing countries}

\section{Although state-driven, Chinese lending takes the form of company-to-company transactions}

Chinese development finance - here defined as including lending from entities controlled by the Chinese government, rarely takes the form of bilateral, i.e. government-to-government, credits. The main creditors are state-owned policy banks such as the Chinese Export-and-Import Bank and China Development Bank as well as a variety of state-owned enterprises. In many cases, the contractual borrowers of the funds are also state-owned entities in recipient countries rather than governments.

\section{Loans often do not involve any cash transfer}

China's state-owned policy banks often choose not to transfer any money to accounts controlled by the overseas borrowers. Instead, the loans are disbursed directly to the Chinese contractor firm that implements the construction project abroad.

\section{Debt owed to China may be under-reported}

Due to the above-mentioned characteristics, China's lending abroad is sometimes not recorded in official public debt statistics of borrowing countries. As a result, a share of Chinese debt is not recorded in official statistics. According to Horn, Reinhart and Trebesch (2019 [25]), more accurate accounting for Chinese lending would result in a 50\% upward adjustment of total external debt stocks for the top 50 recipients of Chinese loans. These include many SSA countries such as Angola, Zimbabwe, Republic of Congo and Zambia. However, these estimates could have been overstated by including non-verified commitments or by including investments that do not take the form of public debt.

Source: Horn, Reinhart and Trebesch, $\left(2019_{[25]}\right)$, China's overseas lending, Kiel Working Paper No. 2132, https://www.ifwkiel.de/fileadmin/Dateiverwaltung/lfW-Publications/Christoph_Trebesch/KWP_2132.pdf.

The share of DAC providers has decreased, although some bilateral providers such as the United States and the United Kingdom have expanded their presence. The share of bilateral DAC providers has decreased from $29.1 \%$ in $2000-2004$ to $19.0 \%$ in $2010-2014$. This was despite the fact that infrastructure finance from the DAC, in absolute terms, increased from USD 7.7 billion cumulated over 2000-2004 to USD 22.2 billion (over 2010-2014). Traditionally, the European Union, France, Germany and Japan have been the largest DAC providers to SSA's infrastructure, and they remain key players. In recent years however, the United States and United Kingdom have entered the landscape. This shift reflects a greater policy focus towards expanded trade and investment relations with Africa, for example through the US-driven Power Africa initiative Figure 2.6). 
Figure 2.6. Among DAC providers, the United States has entered a landscape previously dominated by European and Japanese flows

DAC providers' share of total bilateral infrastructure ODF

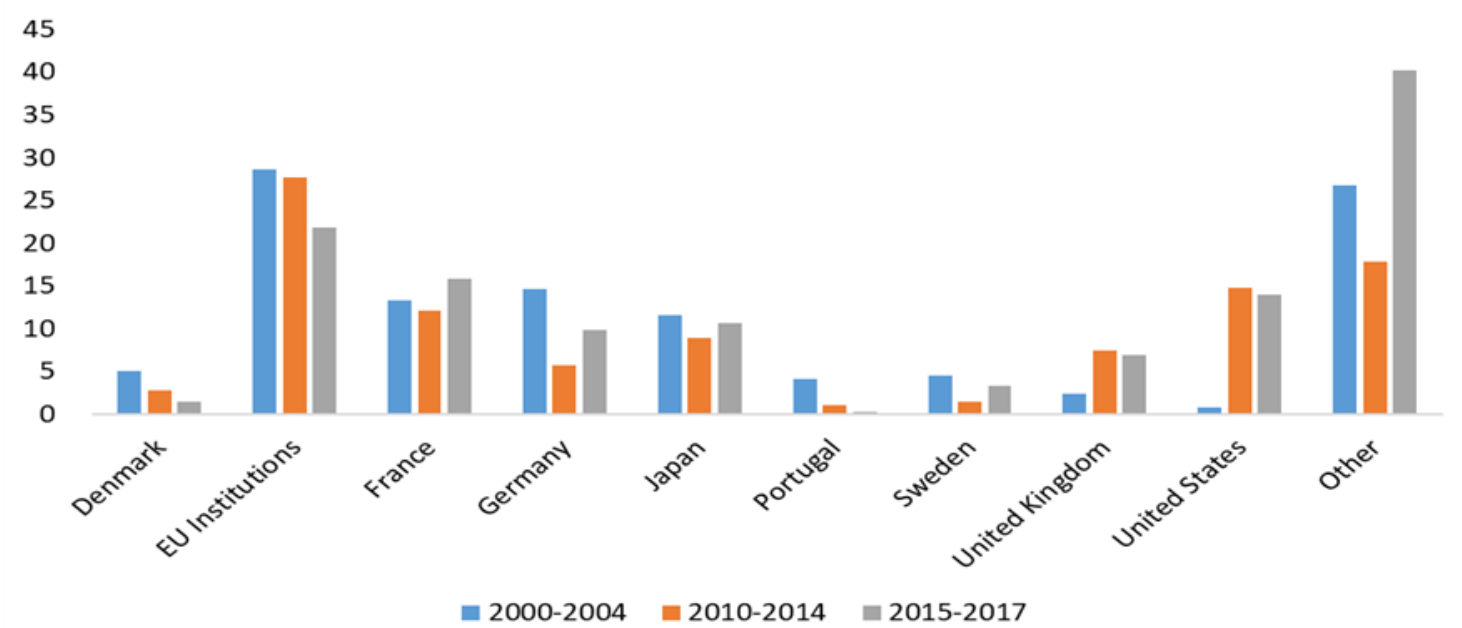

Source: Authors' calculations based on OECD (2019[16]) Creditor Reporting System, , https://stats.oecd.org//ndex.aspx?DataSetCode=CRS1

\subsection{While other actors are targeting increasingly similar destinations, DAC providers have a comparative advantage in low-income countries and the water sector}

The following characteristics can be observed when tracing the changes in the financing patterns of the various actors involved in infrastructure financing in SSA.

- A high share of official flows from DAC providers benefit LICs, and the water sectors. Recently, energy investments have increased, which may be due to the re-orientation towards climate finance and renewable energy by some providers.

- The group of multilateral providers consisting mainly of multilateral development banks such as the World Bank Group and the African Development Bank, but also including vertical funds such as the Climate Investment Funds and the Global Environmental Facility, used to focus on LMICs and the transport sector. But now they are highly invested in energy, and have expanded their presence in UMICs.

- The beneficiaries of Chinese funds were traditionally LMICs, and a majority of the funds were devoted to energy infrastructure. In the more recent period, the respective shares of LICs and UMICs have increased. At the same time, more Chinese finance has flown to the transport sector, a trend which is likely to continue with the launch of the Belt-Road Initiative (BRI).

- PPPs mostly take place in the energy sector of middle-income countries, and the share of PPPs in LICs has declined.

In terms of the income groups of countries targeted by different actors, there seems to be a convergence towards middle-income countries, especially among China and multilateral organisations. 
Figure 2.7. Multilateral providers and China target increasingly similar destination countries

'00-'04 vs '10-'14

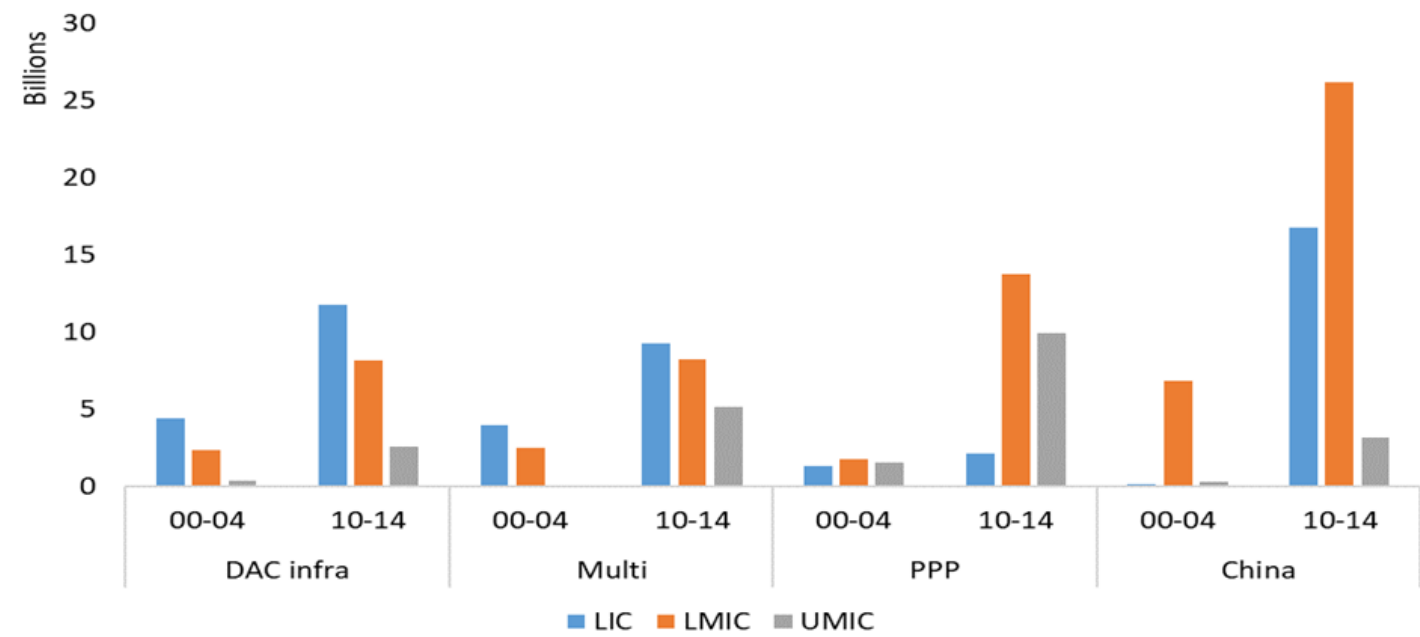

Note: Calculations do not take into account potential overlap between data in official finance databases and the public portion of PPP data (e.g. PPP data and Chinese finance data, PPP data and CRS data).

Source: Authors' calculations based on OECD $\left(2019_{[16]}\right]$, Creditor Reporting System https://stats.oecd.org/Index.aspx?DataSetCode=CRS1; World Bank (2019 $\left.9_{[17]}\right)$, Private Participation in Infrastructure (PPI) database, https://ppi.worldbank.org/en/ppidata; AidData (2017[18]), Global Chinese Official Finance database, https://www.aiddata.org/data/chinese-global-official-finance-dataset.

DAC members have a relative focus on financing to low-income countries, where infrastructure needs present a greater portion of GDP. These countries also have less access to alternative sources of finance such as government borrowing through capital markets. The DAC's assistance, therefore, plays a distinct and critical role. Moreover, the vast majority (over $80 \%$ ) of DAC flows take the form of official development assistance, which is provided at concessional terms, although other official flows, which come at non-concessional terms have increased after 2014. Over half of the financing is provided in the form of grants (Figure 2.8).

Figure 2.8. Official flows from DAC providers is mostly ODA and often takes the form of grants
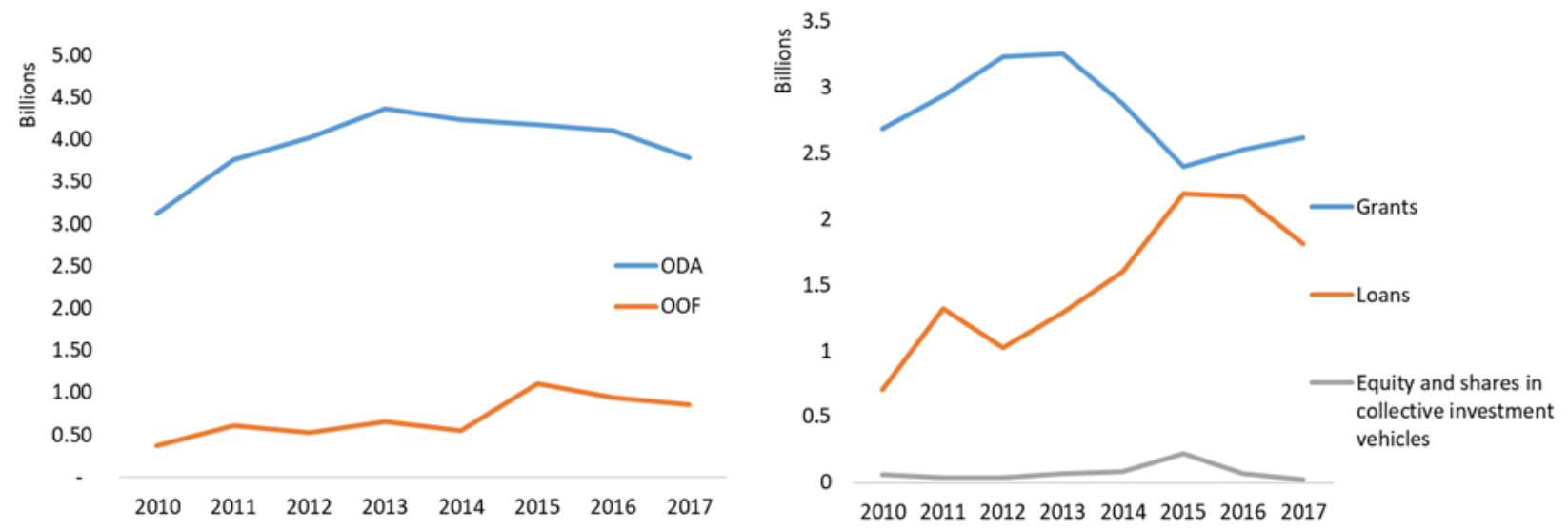

Source: Authors' calculations based on OECD $\left(2019_{[16]}\right)$ Creditor Reporting System, https://stats.oecd.org/Index.aspx?DataSetCode=CRS1. 
In general, the specialisation of actors in terms of the different sub-sectors targeted is becoming less pronounced as well. Chinese and multilateral providers have somewhat converged in the sectors they cover between the early-2000s and the early-2010s.

Table 2.1. Different actors focus on different sub-sectors

\begin{tabular}{l|c|c|c|c|c|c|c|c}
\hline & \multicolumn{2}{|c|}{ Bilateral DAC } & \multicolumn{2}{c|}{ Multilateral } & \multicolumn{2}{c|}{ PPP } & \multicolumn{2}{c}{ China } \\
\hline \multicolumn{1}{c|}{ Period } & '00-'04 & $\prime 10-14$ & '00-'04 & $' 10-14$ & '00-'04 & '10-'14 & '00-'04 & '10-'14 \\
\hline Water & $28 \%$ & $30 \%$ & $28 \%$ & $17 \%$ & $1 \%$ & $1 \%$ & $4 \%$ & $4 \%$ \\
\hline Transport & $49 \%$ & $40 \%$ & $49 \%$ & $37 \%$ & $22 \%$ & $25 \%$ & $12 \%$ & $51 \%$ \\
\hline Communications & $4 \%$ & $3 \%$ & $3 \%$ & $3 \%$ & $25 \%$ & $4 \%$ & $11 \%$ & $5 \%$ \\
\hline Energy & $19 \%$ & $27 \%$ & $20 \%$ & $43 \%$ & $52 \%$ & $70 \%$ & $73 \%$ & $40 \%$ \\
\hline
\end{tabular}

Note: Calculations do not take into account potential overlap between data in official finance databases and the public portion of PPP data (e.g. PPP data and Chinese finance data, PPP data and CRS data). Bilateral DAC providers include the European Union.

Source: Authors' calculations based on Creditor Reporting System $\left(2019_{[16]}\right)$, https://stats.oecd.org/Index.aspx?DataSetCode=CRS1; World Bank (2019[17]), Private Participation in Infrastructure (PPI) database, https://ppi.worldbank.org/en/ppidata; AidData (2017[18]), Global Chinese Official Finance database, https://www.aiddata.org/data/chinese-global-official-finance-dataset

PPPs mainly take place in the energy sub-sector, especially in the more recent period from 2010 to 2014 , where they present almost $70 \%$ of the entire mix. The relative share of transport is also sizable at $25.2 \%$.

DAC providers' financing of water infrastructure has intensified in recent years. The share of water projects in total infrastructure finance has increased from $27.9 \%$ in the period between 2000 and 2004 to $30.1 \%$ between 2010 and 2014. The focus on water infrastructure reflects the DAC's emphasis on financing to sectors that have a high development return but are politically sensitive and often not financially profitable, which make them un-attractive to private investors. Moreover, it is in line with an orientation towards lowincome countries, for whom water is especially important in addressing public health and other development priorities (Abiad, Debuque-Gonzales and Sy, 2017[26]).

However, the share of energy has consistently increased as well, which is partly in response to DAC providers' strong engagement in climate finance and renewable energy investments (Figure 2.9). It may be that the urgency of climate action led multilateral providers to target countries with a greater level of demand and readiness for renewable energy investments. But the reverse is also possible: the strengthened focus on middle-income recipients may have preceded or coincided with the drive for energy investments in SSA. 
Figure 2.9. The increase in energy-related bilateral flows from the DAC are partly driven by renewables

Disbursements, 2014 USD

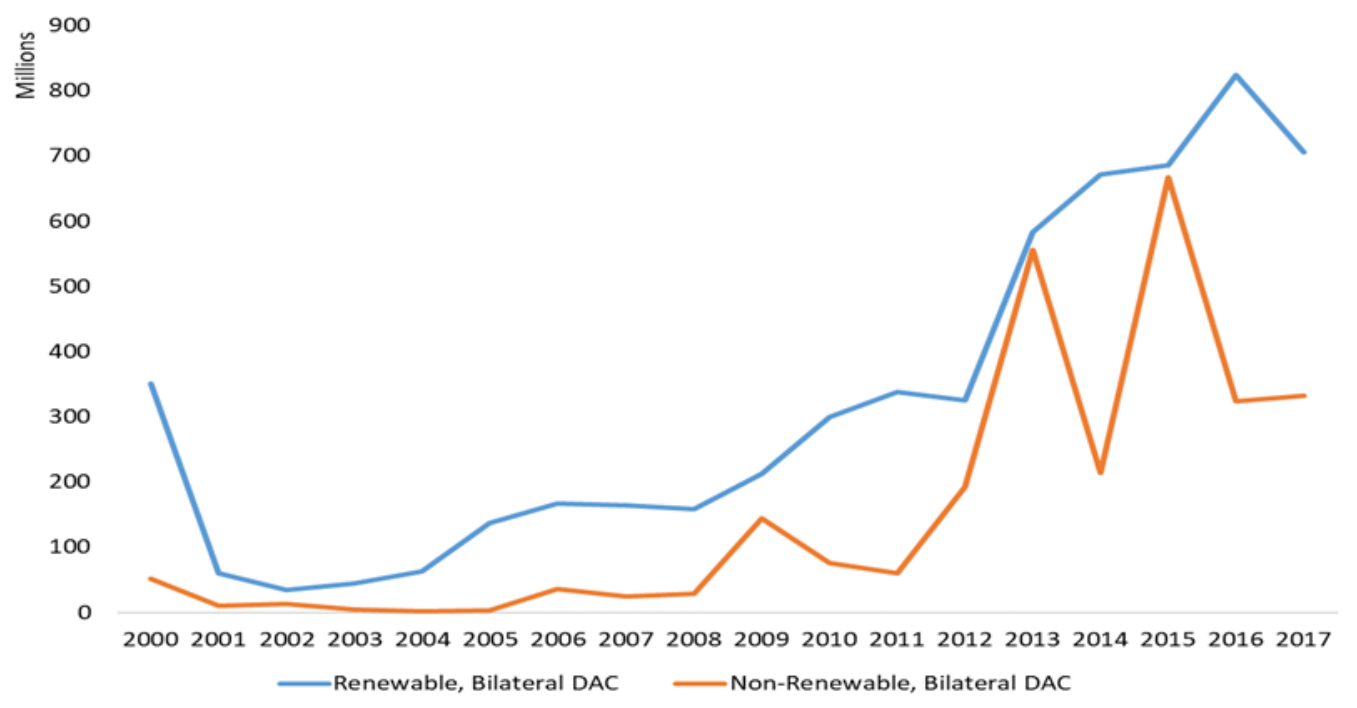

Source: Authors' calculations based on OECD (2019[16] $)$, Creditor Reporting System, https://stats.oecd.org/lnndex.aspx?DataSetCode=CRS1.

The push for energy investments is even more salient in the case of multilateral organisations, who have moved from a focus on transport, towards more financing of energy infrastructure, which grew from $19.5 \%$ of the portfolio to $43.2 \%$. Similar to the case of the DAC providers whose energy portfolio grew, this shift goes hand in hand with a re-orientation towards middle-income countries in multilateral organisations' portfolios.

In the meantime, Chinese financing moved into the reverse direction. In the early 2000s, Chinese funds mostly targeted energy investments, which accounted for more than $70 \%$ of all infrastructure finance. More recently, however, the share of investments in transport have grown from $11.5 \%$ in $2000-2004$ to $51.6 \%$ in 2010-2014.

As a result, Chinese financing of infrastructure is more diversified and the patterns of multilateral and Chinese infrastructure finance increasingly resemble each other, with a focus on energy and transport. Again, this shift in sectoral focus responds to the greater engagement with low-income countries.

One factor that is likely to intensify China's move towards transport infrastructure is the rise of the Beltand-Road Initiative (BRI). First announced in 2013, the BRI is a Chinese initiative that seeks to bring Asia, Europe, Africa and the Middle East closer by building up investment and trade networks through maritime and terrestrial routes and is a major driver of Chinese foreign policy. Since its launch, geographical and sectoral expansion of the BRI can be observed. The BRl's emphasis on connectivity, together with the plan to include East Africa in the so-called Maritime Silk Route, provides another explanation for the surge in transport infrastructure such as ports and railways. 


\section{Box 2.3. What is behind the energy drive in sub-Saharan Africa?}

In shifting towards more energy investments in sub-Saharan Africa, bilateral and multilateral providers of development finance are acknowledging the glaring mismatch between energy needs and supply in the region and the crucial importance of energy in achieving the SDGs.

- On the back of the world's most rapid population growth, energy demand in sub-Saharan Africa grows twice as fast as the global average, and Africa's vast resources and falling technology costs drive double-digit growth in the deployment of renewables.

- However, there is still a critical shortage in energy supply, which has been identified as the most pressing obstacle to achieving economic growth and poverty reduction in the region.

- Nearly half of Africans (600 million people) did not have access to electricity in 2018 , while around $80 \%$ of sub-Saharan African companies suffered frequent electricity disruptions leading to economic losses.

At the same time, a greater emphasis of climate-related support motivates an increase in development finance for renewable energy investments. The emerging global climate finance architecture is well placed to provide financial and technical support to boost the energy sector in SSA. Climate mitigation activities accounted for an average of $93 \%$ of the total climate finance flows in $2015 / 16$, and $74 \%$ of these flows were for renewable energy generation. Several initiatives particularly stand out:

- Power Africa is a U.S. government-led initiative, co-ordinated by the U.S. Agency for International Development (USAID), which comprises 12 U.S. Government agencies, and a diverse coalition of more than 130 public and private sector partners. Its goal is to double access to power across SSA by adding 60 million new electricity connections, as well as increasing installed generation capacity by $30000 \mathrm{MW}$ by 2030 .

- The SE4All initiative is a multi-stakeholder partnership between governments, the private sector, and civil society. Launched by the United Nations Secretary-General in 2011 and expected to conclude in 2030, the SE4All has three objectives: (i) ensuring universal access to energy services, (ii) doubling the share of renewable energy in the energy mix and (iii) doubling the global rate of improvement in energy efficiency. The 44 African countries who joined the SE4All initiative are eligible to receive support in diverse areas such as technical assistance, advisory services, policy dialogue and advocacy.

- China also commits to step up its efforts to provide climate change-related financial and technical support to African countries through announcements of financial support. China's Intended Nationally Determined Contributions (INDC) officially incorporates a pledge to provide USD 3.1 billion (CNY20 billion) to establish the China South-South Climate Cooperation Fund for Climate Change. ${ }^{6}$

The geographical distribution of infrastructure finance also reflects the different priorities of actors, with DAC providers displaying a greater involvement with countries most in need. East African countries have seen the steepest rise in overall infrastructure finance, and are the greatest beneficiaries of the BRI in sub-Saharan Africa. The East African coast is the central component that connects Africa to the Maritime Silk Road. (Edinger and Labuschagne, 2019 [27]) Sudan, Ethiopia, and Kenya are among the countries receiving the greatest amounts of Chinese funds.

\footnotetext{
6 Implementation of the fund has been slow to date, although China has continued to provide support for countries to fight climate change. A recent example is the Memorandum of Understanding signed between China and Botswana for the Provision of Equipment under South-South Cooperation for Addressing Climate Change.
} 
The region that attracts the most PPPs is Southern Africa, which is natural given the presence of relatively wealthy countries such as South Africa and Namibia. These countries are most likely to have the prerequisites for successful PPPs, such as a sound legal and institutional investment framework and profitable market opportunities. PPPs are also used to a significant extent in West Africa.

DAC and multilateral providers have a relatively large presence in West Africa and notably in Central Africa, which is the region that receives the least amount of infrastructure finance, only one third of the amounts flowing to the other regions. As mentioned in above (Figure 1.2) West and Central Africa are indeed the regions that lag behind the most on both quality and quantity dimensions of infrastructure.

Figure 2.10. DAC providers are relatively influential in the neediest places

Logged values of disbursements (2014 USD)

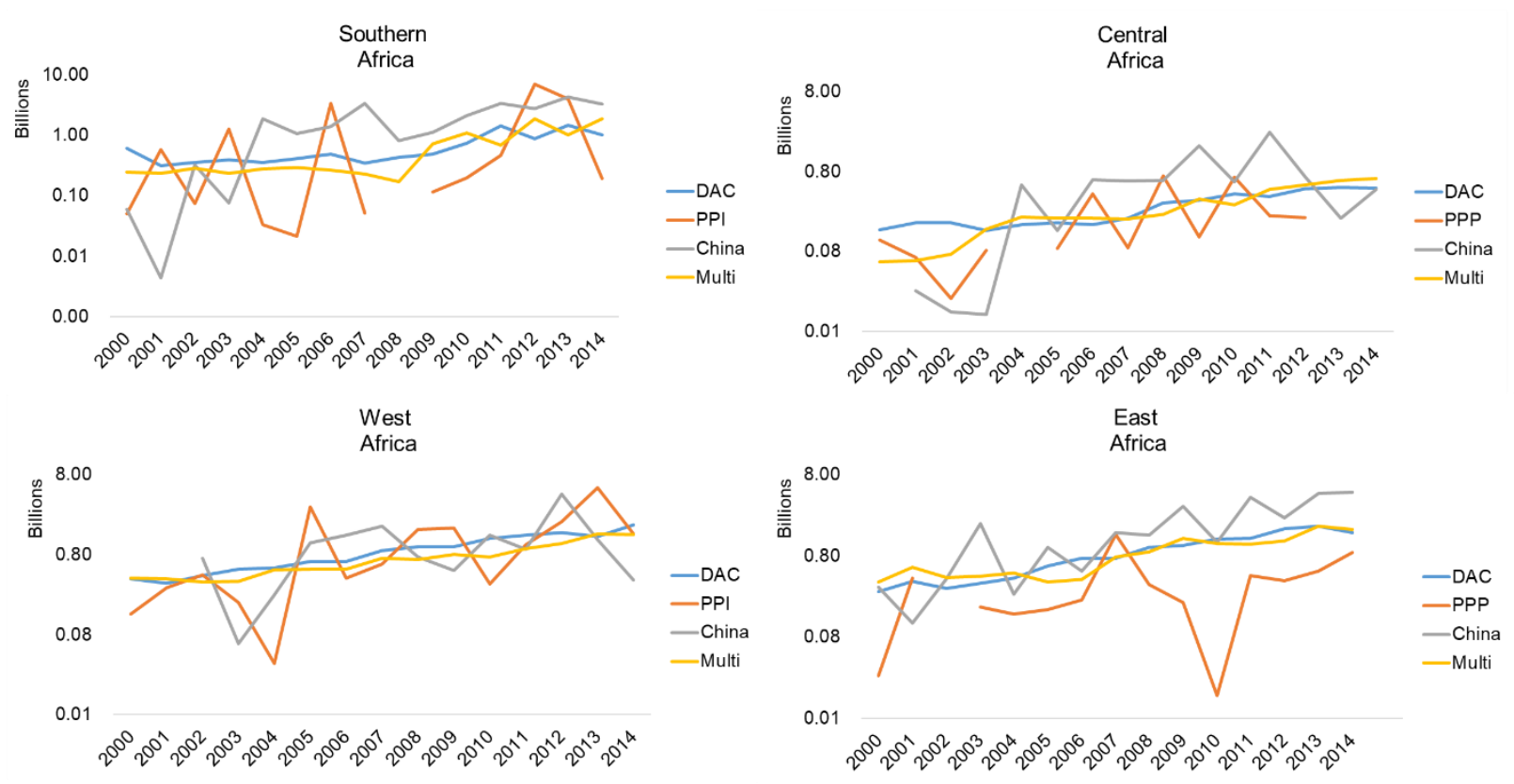

Note: Calculations do not take into account potential overlap between data in official finance databases and the public portion of PPP data (e.g. PPP data and Chinese finance data, PPP data and CRS data).

Source: Authors' calculations based on OECD (2019[16]) Creditor Reporting System, https://stats.oecd.org/lndex.aspx?DataSetCode=CRS1; World Bank (2019 $\left.{ }_{[17]}\right)$, Private Participation in Infrastructure (PPI) database, https://ppi.worldbank.org/en/ppidata; AidData (2017 $\left.{ }_{[18]}\right)$, Global Chinese Official Finance database, https://www.aiddata.org/data/chinese-global-official-finance-dataset. 


\section{Key policy issues - reconciling debt sustainability with infrastructure financing}

\subsection{The availability of more infrastructure finance can raise debt sustainability concerns}

The greater availability of infrastructure finance, including from non-traditional sources, is often associated with an increase in public debt levels in SSA.

After public debt levels in SSA countries had decreased significantly due to major debt relief initiatives in the 2000's, they are now rising again. Since 2011, external debt to GDP has increased for all sub-regions and most steeply Southern Africa ${ }^{7}$. As of December 2020, five countries in SSA are in debt distress, and another 13 countries have a high risk of debt distress. ${ }^{8}$

Figure 3.1. Debt vulnerabilities make it difficult for countries to invest more in infrastructure

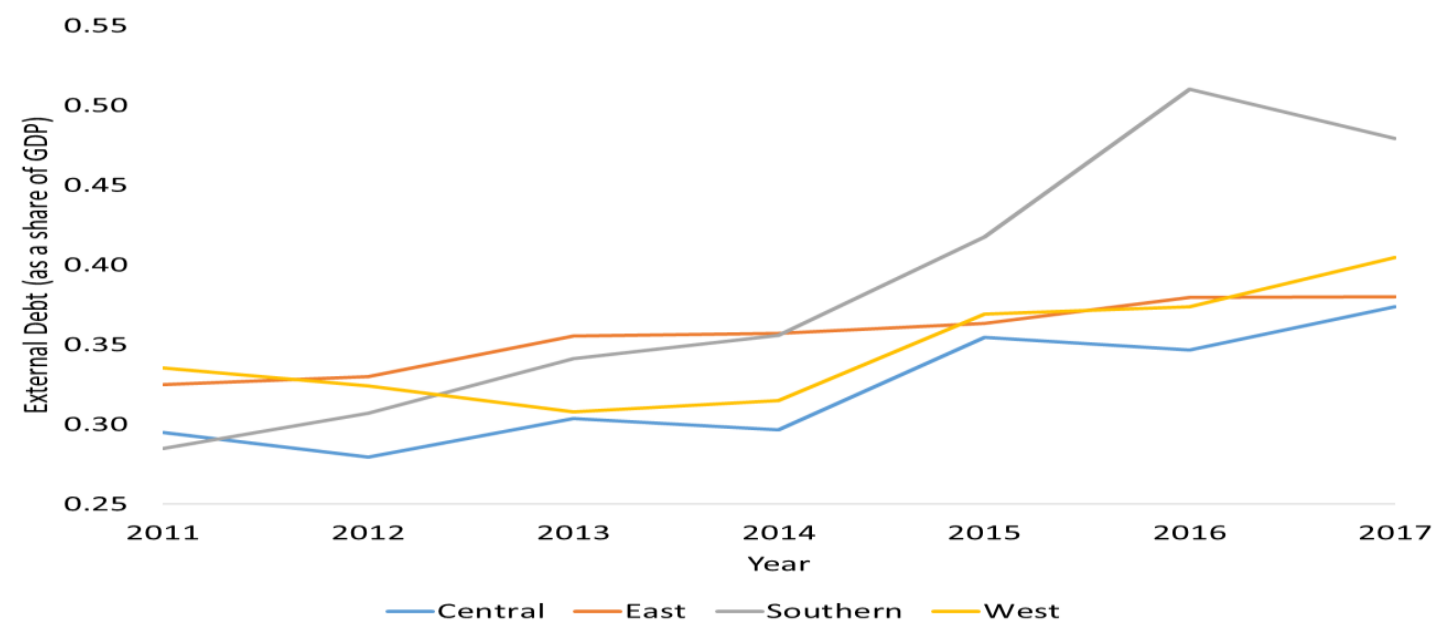

Source: Authors' calculations based on World Bank (2020[1] $)$, World Development Indicators database, https://data.worldbank.org/products/wdi.

\footnotetext{
7 This was especially driven by Zambia and Mozambique.

${ }^{8}$ The countries in debt distress are: Republic of Congo, Mozambique, Somalia, Sudan and Zimbabwe. The countries at high risk of debt distress are: Burundi, Cabo Verde, Cameroon, Central African Republic, Chad, Ethiopia, Gambia, Ghana, Kenya, Mauritania, Sierra Leone, South Sudan and Zambia.
} 
Resorting to debt can put a burden to fiscal sustainability. Borrowing can be a useful way to finance public investments. If public investments are solely financed by increases in tax rates, they can discourage private investments. Rather than abruptly raising tax rates to fully finance new investments, borrowing can help governments take a gradual approach to fiscal adjustment. If such investments have high returns, they can contribute to economic growth and the broadening of the tax base, bringing in the necessary revenue to pay back the debt without extensive increases in tax rates. (Buffie et al., 2012[28]) However, this strategy involves significant risks. For example, in light of weak institutional capacities, governments can fail to identify and invest in high-return projects.

Moreover, a high debt burden risks crowding our private investments for infrastructure. For example, high levels of public debt can discourage private investors in a public private partnerships, because government payments and guarantees will seem less reliable. Those public payments, however, are crucial key infrastructure sectors such as road maintenance or the water and sanitation sub-sectors.

The push for infrastructure investments is a potential driver behind the debt build-up. There is a positive correlation between the change in external debt levels and increases in public investment, used here as a proxy for infrastructure investment. This implies that, at least, some of the debt is associated with governments' push for more infrastructure spending (Figure 3.2).

\section{Figure 3.2. Debt is used to finance infrastructure investments}
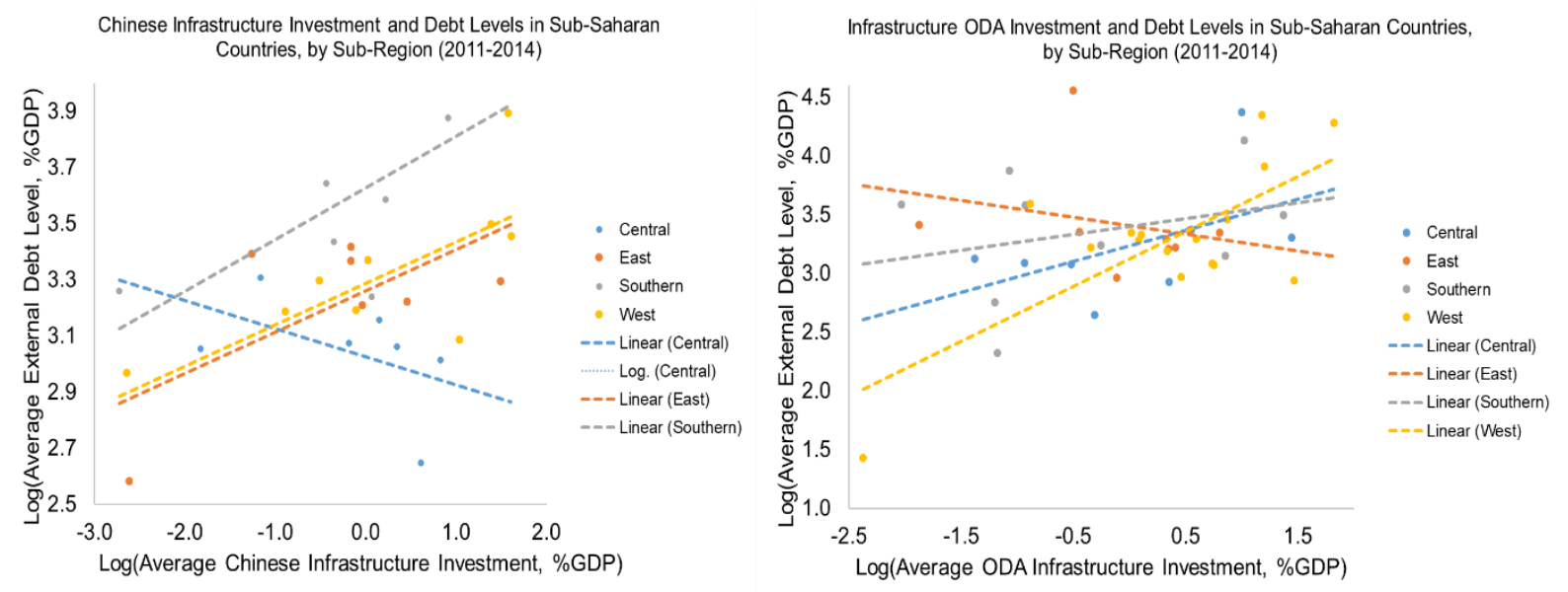

Note: Chinese data are reported only when the average investment in infrastructure over the sample period was greater than zero.

Source: Authors' calculation based on OECD $\left(2019_{[16]}\right)$ Creditor Reporting System, https://stats.oecd.org/Index.aspx?DataSetCode=CRS1; AidData $(2017[18])$, Global Chinese Official Finance database, https://www.aiddata.org/data/chinese-global-official-finance-dataset; World Bank (2020[1]), World Development Indicators database.

In regions that have a high reliance on infrastructure finance from one type of actor, access to resources from other actors is negatively correlated with aggregate debt levels. This holds regardless of the type of actor.

In Central Africa, where the DAC and multilateral organisations are dominant players, additional Chinese investments in infrastructure are inversely related with the change in external debt. For East Africa, where China is a predominant source of financing infrastructure, additional ODF flows from DAC providers and multilateral organisations are associated with lower debt levels. Closer analysis could investigate the reasons for this phenomenon. Non-dominant actors may strategically choose countries that owe less debt to the dominant actor in the region. Another reason can be that non-dominant actors have a mitigating effect on debt levels, potentially influencing the conditions and terms of lending. For example, the presence of alternative lenders can help borrowing countries to negotiate more favourable terms such as lower 
interest rates and longer maturities, which render the overall debt structure more favourable. For instance, there are cases where the grace period for loans are not adequate given then ramp-up period of a project. More negotiating power for borrowing countries could give them access to conditions that are more aligned with the nature and financing needs of their infrastructure projects.

The type of actor can have an effect on the level of debt servicing costs, however. While data on concrete debt servicing costs are hard to find, by their very nature concessional lending from DAC members is likely to carry lower debt servicing costs than commercial lending from capital markets. The terms and interest rates of Chinese finance heavily depend on the lender, and type of project. Considering that a large part of the lending from Chinese actors is commercial, it is probable that the cost of debt from DAC members will be lower in comparison to debt from alternative sources.

A recent study by the Center for Global Development (Morris, Parks and Gardner, 2020[29]) suggests that while China offers interest free loans as part of its foreign aid programme, they make up less than $5 \%$ of all Chinese loan commitments. Chinese lending also includes concessional loans, which are subsidised by the Chinese Government's foreign aid budget, as well as preferential export buyer's credits. In the early 2000s, China Eximbank's concessional loans had interest rates around $4 \%$, but in more recent years, they have stabilised at around $2 \%$, with 20 -year maturity. In comparison, the World Bank provides lending to IDA countries at $1.54 \%$ fixed interest rates and 40 -year maturities, and the least concessional IBRD lending for long-term maturities (18 to 20 years) come at a flexible rate of LIBOR plus 205.

While the changed composition of infrastructure finance providers may not affect debt levels per se, it involves a loss of transparency. China, which has gained significant influence as a lender in SSA countries, is neither member of the DAC nor of the Paris Club, the major international organisation of official creditors. As such, China does not publish data on the volumes and terms of its lending, as well as debt restructuring efforts (Horn, Reinhart and Trebesch, $2019_{[25])}$. Since SSA countries themselves often lack data on the amount of debt they owe to foreign creditors, the full amounts they owe to non-DAC and particularly Chinese lenders are often hidden. Ensuring transparency is even more complicated due to the practice of collateralisation ${ }^{9}$ (Mustapha and Prizzon, 2018[30]). This makes it challenging to accurately monitor debt and take timely precautionary measures to prevent and mitigate debt crises.

China's increased influence also affects the prospects and outcomes of potential debt restructuring. One of the main causes for concern over the significant weight of China in sub-Saharan Africa's is the fact that China is not a member of the Paris Club, which is the principal international forum for restructuring official bilateral debt. (See Box 3.2) Even if China participates as an observer in Paris Club meetings on an ad hoc basis, it has not engaged in a multilateral framework for restructuring its bilateral official deb. Although there have been several cases of Chinese debt restructuring, they took place on a bilateral and often opaque way while a co-ordinated approach would allow for a more transparent process (Kratz, Feng and Wright, 2019 $\left.{ }_{[3]}\right)$.

Experience also shows, however, that China has collaborated in debt restructuring when wider debt restructuring mechanisms and frameworks were in place. In the context of the HIPC/MDRI initiative, for example, China provided $85 \%$ of its total expected debt relief (IMF/WB, 2019 ${ }_{[31]}$ ). Increased DAC engagement in financing infrastructure in SSA can help encourage China to participate in mechanisms such as the Paris Club to share information with different creditors and co-ordinate potential debt restructuring.

\footnotetext{
${ }^{9}$ Especially in resource-rich countries, China often secures a loan by locking in proceeds from the sale of commodities such as oil or minerals to from the debtor country. In most cases, this locked revenue originates from the sale of the specified commodity to a Chinese SOE, and is guaranteed by a resource-focused parastatal of the debtor country.
} 


\section{Box 3.1. Debt restructuring in light of the COVID-19 crisis}

As a key lender in the region, China is expected to play a major role in supporting a reduction of the debt burden of developing nations in the context of the COVID-19 crisis. As a member of the G20, it supported the G20-sponsored Debt Service Suspension Initiative (DSSI), which was agreed upon on 15 April 2020.

According to OECD estimates, using data recently published by the World Bank, if borrowers and public and private creditors were to participate fully, the DSSI would result in a suspension of USD 21.8 billion payments for eligible countries in 2020 (of which about half is official). If multilateral development banks participate, this could add an additional USD 9.7 billion (OECD, 2020[32]). Yet, actual participation will be well below those amounts: only 41 eligible countries have requested participation so far.

China could represent about $30 \%$ of the total debt service due in 2020 , combining official and private sources. According to recent reports, it already agreed to 10 of 20 requests made by eligible countries. China has agreed to restructure official loans of CIDCA and of China Exim Bank, but it considers that loans from the China Development Bank (CDB), which are made at commercial rates, should be considered as private, although this position could evolve.

While debt restructuring has been a frequent feature of Chinese development policy, sums involved are usually relatively small and tend to opaque. In previous instances (e.g. Republic of Congo in 2019), the terms of Chinese debt restructuring had to be separately applied to different loans, which differs from the more streamlined Paris Club processes, where the whole of the debt stock is negotiated (OECD, 2020[32]).

In the longer run, more fundamental questions of sustainability will be raised, increasing the potential need for other debt relief mechanisms. China has not been part of broader multilateral co-ordination initiatives on the subject of debt relief, but President Xi Jinping made clear in his speech to African leaders that China would be encouraged to participate.

The presence of DAC providers as alternative sources of financing, however, can lead to an improvement of the debt environment. Recent studies suggest that developing countries' debt negotiations with Chinese entities lead to a variety of outcomes. While there are some cases of asset seizure, negotiations can also result in refinancing, extension of deadlines as well as debt forgiveness. The most important factor that adds leverage and bargaining power to borrower countries is the availability of alternative financing sources (Kratz, Feng and Wright, 2019[3]).

Moreover, collaboration among SSA countries on debt management and restructuring can increase individual countries' negotiating power as well. While each country may be on its own dealing with lenders, they can share knowledge based on their experience of debt negotiation and restructuring including with Chinese lenders. This finding highlights that continued DAC engagement in infrastructure in SSA, by effectively mitigating the risks of potential debt crises, can be one factor in countering debt sustainability concerns. 


\section{Box 3.2. Emerging creditors with non-traditional financing practices intensify debt sustainability concerns}

The Paris Club, an informal group of 22 official bilateral creditors, is recognised by the G20 as the principal international forum for restructuring official bilateral debt. This is therefore also an important forum for SSA countries to restructure sovereign debt. It was instrumental in providing debt relief through the HIPC initiative, for example.

\section{Figure 3.3. Most permanent members of the Paris Club are in the DAC}

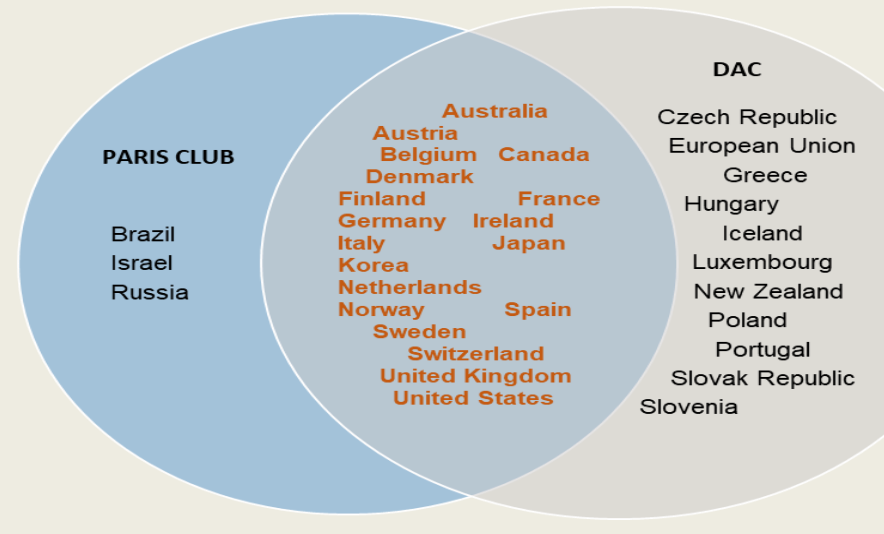

Source: Authors' illustration

However, most non-DAC providers who have gained in influence since the 2000s do not belong currently to the Paris Club. They include China but also Arab countries such as Kuwait and Saudi Arabia, who for a number of SSA countries are among the largest providers of finance. As for those SSA countries that are currently in debt distress or at high risk thereof, the share of lending from nonParis creditors exceeds the share of Paris Club members (Figure 3.4). This evolution stressed the need for co-ordination among creditors. Nevertheless, it is important to recall that non-Paris Club members can participate in Paris Club negotiations (more than a third of debt treatments provided by the Paris Club has involved non-Paris Club members). Furthermore, the Paris Club has developed an active anchoring strategy to progressively expand its membership to major emerging creditors, in view of increasing its representation in the context of the global creditor base's evolution. In recent years the Paris Club added Israel (2014) and Korea and Brazil (2016) as new members. China and South Africa are participating in the work of Paris Club on an ad-hoc basis, while India started attending as an observer in 2019 and an enhanced engagement with Saudi Arabia has started recently. The influence of non-official creditors, i.e. commercial lenders, has also increased. This is partially due to the rise in sovereign bond issuances. As shown in Figure 3.4 the median share of commercial lending including through sovereign bonds in SSA countries in debt distress or at high risk is $21 \%$, considerably higher than the median share of Paris Club lending at $3 \%$. In this context, the Paris Club meets regularly with the Institute for International Finance in order to ensure a coordination between official bilateral creditors and private creditors. 


\section{Figure 3.4. Next to multilaterals non-Paris Club members and commercial lenders have become} important creditors

Relative share of total debt in countries in debt distress and high risk thereof

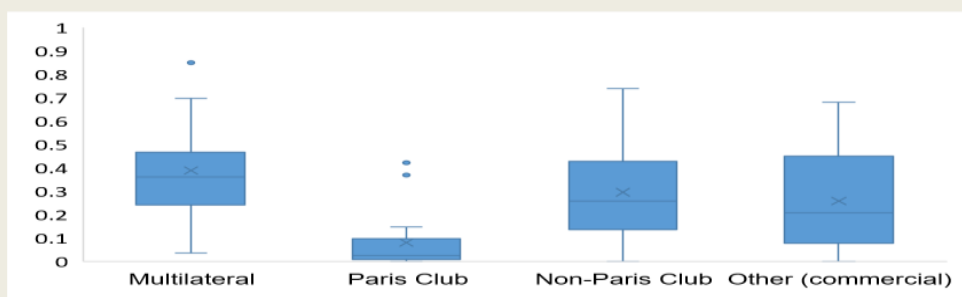

Source: Authors' calculation based on IMF/World Bank Debt Sustainability Analyses (2017-2019[33]) of, Burundi, Cabo Verde, Cameroon, Central African Republic, Chad, Djibouti, Ethiopia, Gambia, Ghana, Mauritania, Mozambique, Sao Tome and Principe, Sierra Leone, South Sudan, Sudan, Zambia, Zimbabwe.

\subsection{But the quality of spending matters more}

More than absolute levels of infrastructure finance, quality of spending is important to prevent unsustainable debt accumulation. SSA countries themselves bear the responsibility for making the best of the resources that are available to them.

Although debt is often raised to finance infrastructure projects, it could be diverted to fund other expenditures. Several countries issued Eurobonds with the explicit aim to use the proceeds for public infrastructure projects. This purpose is recorded in formal statement that usually accompany sovereign bond issues. However, debt raised for infrastructure investments does not always result in a corresponding rise in public investment, suggesting that some funds are diverted to finance other budget lines. For example, after raising bond proceeds amounting to USD 750 million in 2007, Ghana did not see a palpable rise in public investment levels but instead public salaries increased (Mecagni et al., 2014[34]).

High levels of corruption can lead to expansion of public debt, which is not put to productive use. In Mozambique, for example, quasi-public entities took out debt backed by government guarantees and amounted to over USD 2 billion without fulfilling constitutional and legal requirements.

Public consumption expenditure, which is less effective in enhancing economic growth, often rises together with public investment. This is especially true of countries facing high debt pressures. Between 2011 and 2017, public investment increased in 22 SSA countries. In 14 of these 22 countries, government consumption increased at the same time. Government consumption includes public sector salaries and has less of a growth-enhancing and pro-development effect, especially in developing countries (Izquierdo et al., 2019 [35]). In nine countries, only consumption expenditure expanded while public investment decreased. This is quite worrying, as these countries often saw a steep increase in their public debt levels. One of them namely the Republic of Congo is even in debt distress. 
Figure 3.5. More sub-Saharan African countries saw an increase in government consumption than in investment

Changes in government consumption and/or public investment levels by country, 2011-2017

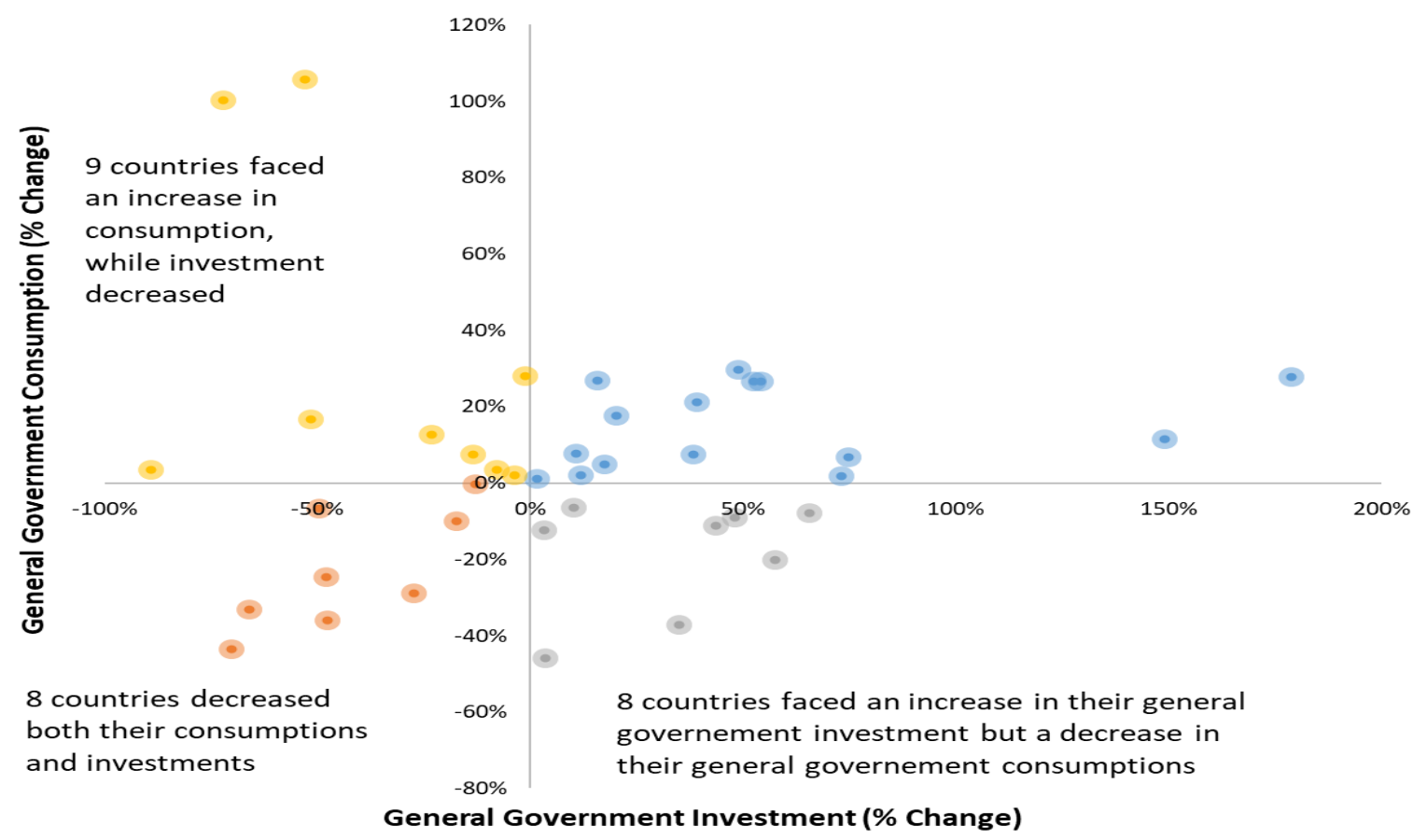

Source: Authors' calculations based on World Bank (2020[1]), https://data.worldbank.org/products/wdi, World Development Indicators database; International Monetary Fund (2017[19] $)$, Investment and Capital Stock Dataset, https://www.imf.org/external/np/fad/publicinvestment/\#5.

Even where external debt is used to finance public investment, infrastructure investments are often made without paying due regard to debt sustainability considerations. For example, since infrastructure projects do not always generate foreign earnings, financing them through foreign currencydenominated debt can generate inherent mismatches between the earning capacity and future debt payment obligations. An extensive reliance on external resources to finance infrastructure in SSA can have dire consequences in the long-term.

Inefficient infrastructure investments can compound debt sustainability problems. Weaknesses in project prioritisation and public investment management lower the rates of return on investment. With low rates of economic return, however, infrastructure projects will fail to enable governments to repay the debt that has potentially been raised to finance the investment.

Public investment efficiency is especially low in SSA. As a region, SSA faces the largest public investment efficiency gap in the world. SSA countries could increase their public investment efficiency by an average $54 \%$ to reach the level of best-performing countries with a similar level of public capital stock and income per capita (Barhoumi et al., 2018[36]). This finding is based on an indicator that measures the actual performance of economic and social infrastructure, e.g. length of road network, electricity production, against the investments that is involved. 
Figure 3.6. Sub-Saharan Africa countries face the largest public investment efficiency gap

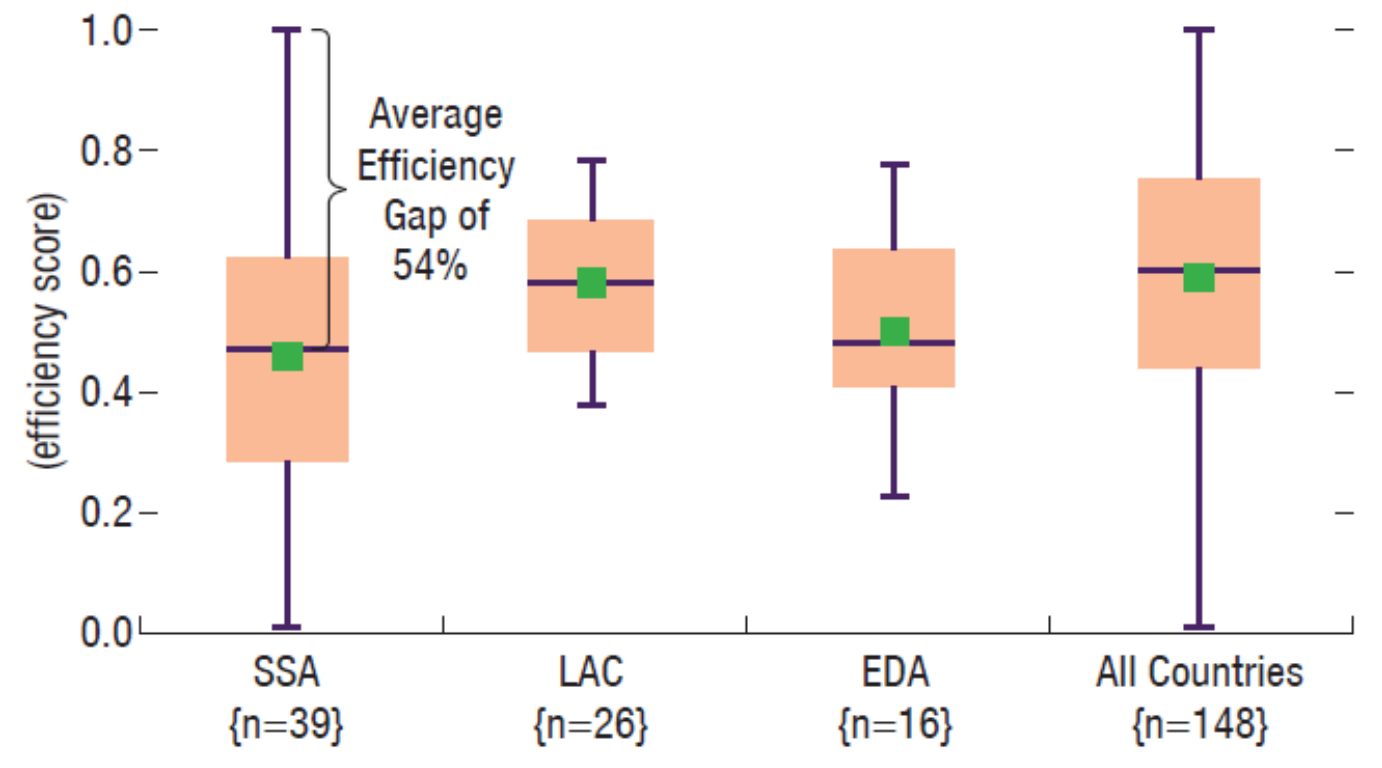

Source: Barhoumi et al $\left(2018_{[36]}\right)$, Public Investment Efficiency in Sub-Saharan African Countries, https://www.imf.org/ /media/Files/Publications/DP/2018/45953-dp1809-public-investment-ssa-june-19.ashx.

Reasons for inefficient public investments are weak institutions, low levels of debt management and bad project management practices. Local institutions often lack the ability to conduct evidencebased cost-benefit analysis to identify and prioritise strategically important projects. Weak project management often leads to time and cost overrun, resulting in financial un-sustainable projects. This is due to poor timing of project appraisals, problems occurring during the procurement process as well as poor project preparation due to weak capacities. (Briceño-Garmendia, Smits and Foster, 2008 $[37]$ )

High levels of corruption lead to diversion of funds for infrastructure investment. According to the OECD, half of bribes paid are in industries with the largest spending on infrastructure, such as the construction (15\%) and transportation (15\%) sectors (OECD, 2014 $\left.{ }_{[38]}\right)$. This is due to the complexity of the project cycle, the uniqueness of projects, and direct control by a government. (Stansbury, 2005[39]) With an average score of 32 out of 100 , sub-Saharan Africa is the lowest scoring region on the Corruption Perceptions Index (CPI).

Politicisation of infrastructure investments can further weaken efficiency. Public investment projects that receive political support are not necessarily the ones that bring the greatest development gains. For example, $30 \%$ of assets in sub-Saharan Africa are in need of rehabilitation, and the share reaches more than $40 \%$ for rural roads. One way to alleviate this problem would be to devote more funds to maintenance. Since the cost of rehabilitation exceeds by far the cumulative cost of preventive maintenance, re-allocating some of the funds from investment to maintenance would increase efficiencies. According to one estimate, every US dollar spent on road maintenance saves an estimated USD 4 on rehabilitation. (BriceñoGarmendia, Smits and Foster, 2008[37] However, new construction and rehabilitation are often prioritised over maintenance, for reasons of visibility. 


\title{
3.3. The importance of quality investments are increasingly recognised by providers of infrastructure finance
}

\begin{abstract}
Amid growing concerns around debt sustainability and its trade-off with infrastructure investment, there is a renewed focus on the quality dimension of infrastructure finance.
\end{abstract}

To ensure that financial resources spent on infrastructure enhance sustainable development and mitigate the risk of debt crises, a thorough examination of the quality and uses of infrastructure finance is necessary. This involves a holistic approach taking into account how infrastructure will contribute to economic growth, which social groups the infrastructure is likely to benefit, what environmental consequences it will entail and how cost efficient it will be.

To ensure economic viability, it is critical to have good project preparation facilities that undertake transparent cost benefit comparisons and open tending. Often, simple upgrading and repairing exiting infrastructure can have a bigger economic benefit.

Increasingly, linkages between economic, social and environmental sustainability are being emphasised. For example, climate-resilient infrastructure leads to fewer disruptions and reduced economic impacts, with an overall net benefit estimated at USD 4.2 trillion (in developing countries only). This translates into a USD 4 benefit for each dollar invested in resilience. (Hallegatte, Rentschler and Rozenberg, 2019 ${ }_{[40]}$ )

Shifts in climate policy could increase the risk of stranded assets. (Asset stranding, which is the loss in asset value due to unanticipated or premature write-down, devaluations or conversion to liabilities, for example, related to fossil fuel-intensive infrastructure risks further deteriorating the economic viability of infrastructure investments and therefore affects debt sustainability. As more and more private investors are targeting sustainable infrastructure, there is an additional commercial and debt sustainability benefit to governments moving towards this type of infrastructure.

Recently, there have been attempts including from DAC members to address the sustainability concerns of infrastructure investments.

In recognition of the importance of quality infrastructure investment, the $\mathrm{G} 7$ endorsed the "Ise Shima Principles for Promoting Quality Infrastructure Investment" under the Japanese presidency in 2016, which was followed by a G20 endorsement of Principles for Quality Infrastructure Investment in June 2019.

Another recent initiative is the Blue Dot Network (BDN), which was announced by the United States, Japan, and Australia in November 2019 at the Indo-Pacific Business Forum in Thailand. BDN will provide assessment and certification of infrastructure development projects worldwide on measures of financial transparency, environmental sustainability, and impact on economic development in accordance with existing international standards such as the G20 principles for Quality Infrastructure Investment. The aim is to assure private investors - including U.S. pension funds and insurance companies with a combined portfolio of USD trillions in long-term assets - of the economic, environmental and social sustainability of infrastructure investments to mobilise their resources to address the infrastructure gap worldwide.

Based on its standard setting role and multidimensional experience, the OECD provides a suitable platform for policy guidance related to quality infrastructure finance. The recently launched Sustainable Infrastructure Policy Initiative gathers the knowledge and expertise across OECD directorates to assist countries in their efforts to make infrastructure investments more sustainable. 


\section{Box 3.3. OECD's Sustainable Infrastructure Policy Initiative}

The OECD launched the Sustainable Infrastructure Policy Initiative to pilot the development of instruments, analysis and data related to sustainable infrastructure using expertise from 17 directorates and agencies across the organisation, and building on more than 100 OECD projects related to these issues. This work will provide all stakeholders with credible evidence-based guidance and support for implementing sustainable sub-national, national, and international infrastructure investment. The initiative will act as a global platform for exchange between policy makers and stakeholders. As a part of this initiative, the OECD published the OECD Compendium of Policy Good Practices for Quality Infrastructure Investment which provides a unique set of existing integrated and multidisciplinary international good practices that policy makers and practitioners in both developed and developing economies can use on a voluntary basis. The Compendium is complemented by the OECD Implementation Handbook for Quality Infrastructure Investment, an analytical and operational tool that focuses on selected issues and challenges for quality infrastructure investment and provides implementation solutions through concrete examples and case studies.

\section{Figure 3.7. The five pillars of the OECD Sustainable Infrastructure Policy Initiative}

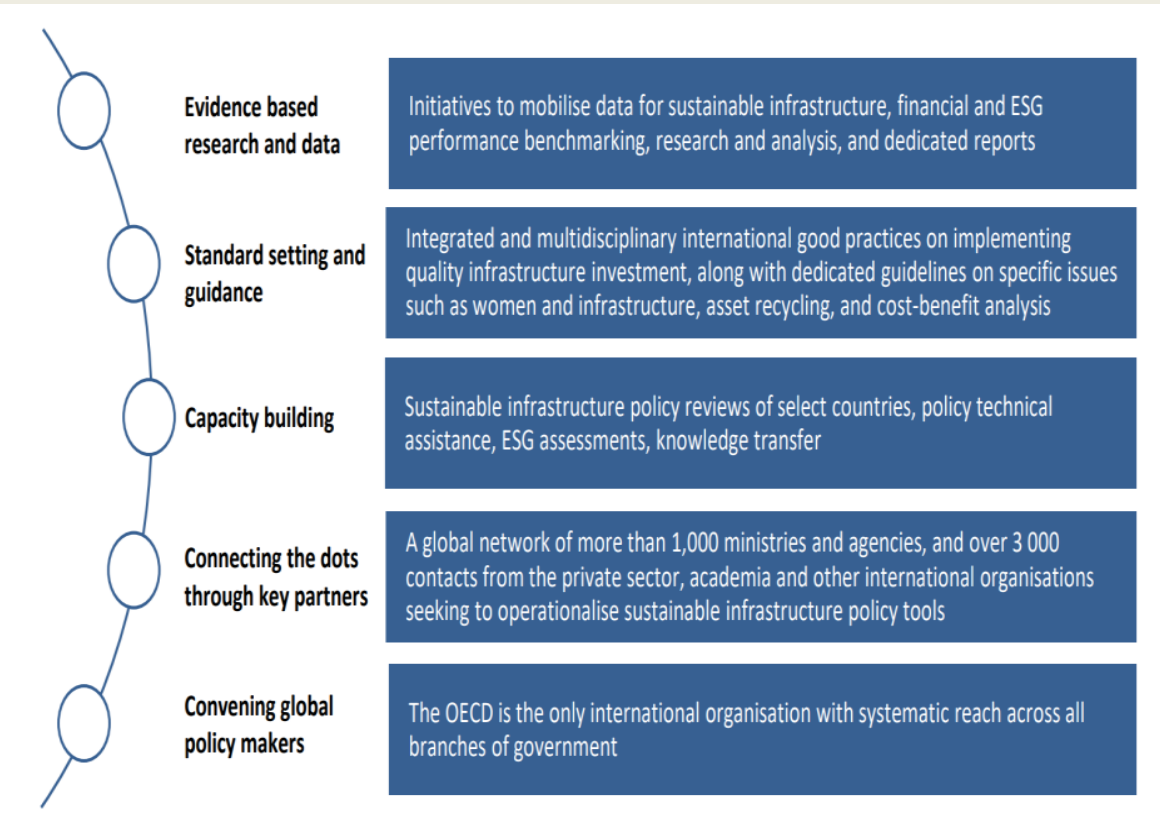

Source: OECD (2019[41]), Sustainable Infrastructure Policy Initiative, http://www.oecd.org/finance/Sustainable-Infrastructure-PolicyInitiative.pdf

DAC providers, in particular, tend to allocate more infrastructure finance to countries with higher levels of public investment efficiency. In general, low levels of public investment efficiency do not seem to affect SSA countries' ability to receive development finance. The correlation between public sector efficiency as measured by the Public Sector Management Quality Index was positive in 2006, but in 2011 and 2017, respectively, the relationship became weaker and even reversed to a negative relationship. (Figure 3.8) This can imply that official development finance in SSA has become less responsive to public sector efficiency. 
Figure 3.8. Official development finance does not target countries with higher public sector efficiency in sub-Saharan Africa

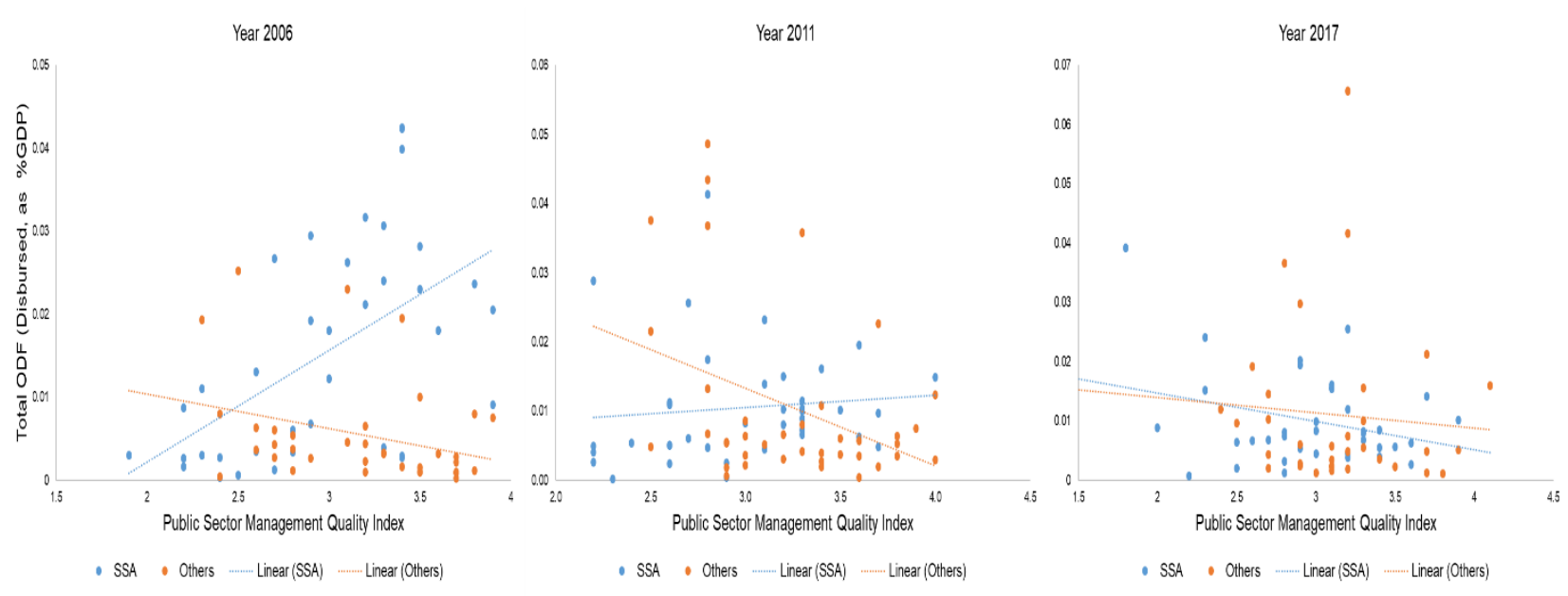

Note: To measure the PSM Quality this paper uses the "CPIA public sector management and institutions cluster average", an unweighted average of several indexes. Specifically: property rights and rule-based governance, quality of budgetary and financial management, efficiency of revenue mobilisation, quality of public administration, and transparency, accountability, and corruption in the public sector.

Source: Authors' calculation based on OECD $\left(2019_{[16]}\right)$ Creditor Reporting System, https://stats.oecd.org/Index.aspx?DataSetCode=CRS1; World Bank (2018[42]], Country Policy and Institutional Assessment https://databank.worldbank.org/reports.aspx?source=country-policy-andinstitutional-assessment

Figure 3.9. Countries with higher public sector efficiency receive more development finance for infrastructure
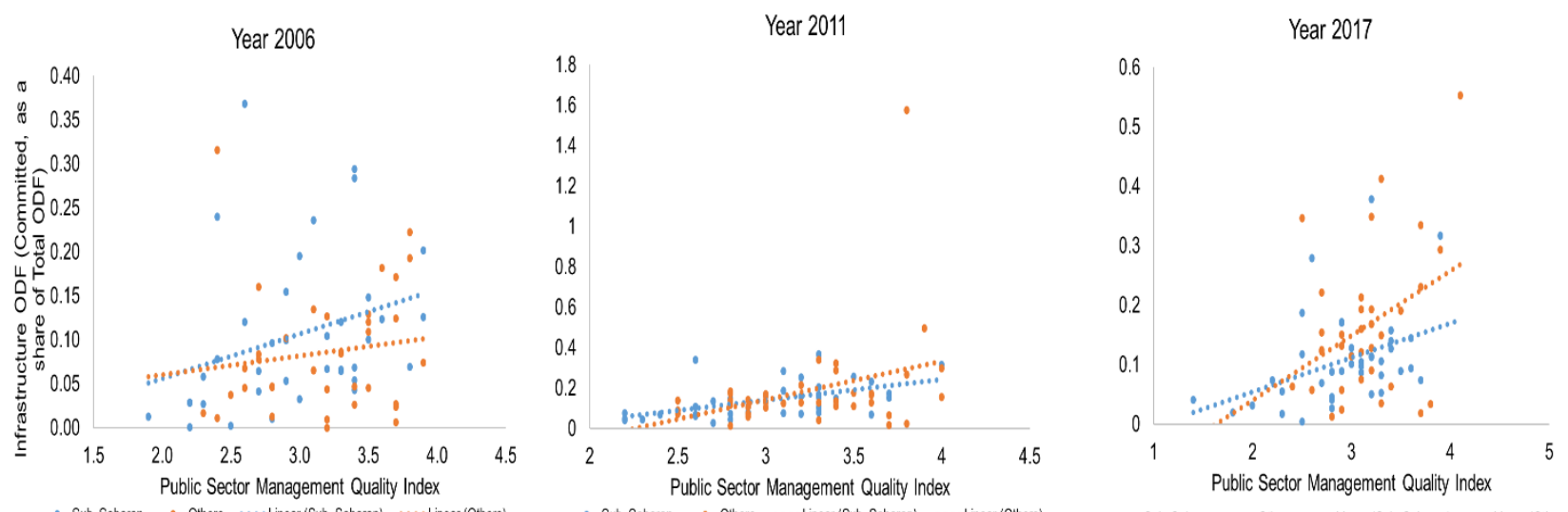

Note: To measure the PSM Quality this paper uses the "CPIA public sector management and institutions cluster average", an unweighted average of several indexes. Specifically: property rights and rule-based governance, quality of budgetary and financial management, efficiency of revenue mobilisation, quality of public administration, and transparency, accountability, and corruption in the public sector.

Source: Authors' calculation based on Creditor Reporting System (2019[16]), https://stats.oecd.org/lndex.aspx?DataSetCode=CRS1; World Bank (2018[42]], Country Policy and Institutional Assessment https://databank.worldbank.org/reports.aspx?source=country-policy-and-institutionalassessment.

However, for infrastructure finance, in particular, there seems to be a positive relationship with public investment efficiency (Figure 3.9). Countries with higher levels of efficiency receive a higher share of development finance in infrastructure sectors, suggesting that official development finance in infrastructure tends to target countries with high public sector efficiency. 


\section{Policy implications of DAC members' role in sub-Saharan African infrastructure finance}

\subsection{Why the DAC should care}

Debt sustainability concerns can cause hesitance among DAC providers to invest in infrastructure.

The experience of debt crises in sub-Saharan Africa is still fresh in the memory of members of the DAC. Growing concerns about debt sustainability in SSA could lead to further withdrawal of the DAC as a provider of infrastructure finance.

\section{However, providing continued support for more and better infrastructure finance is key to achieving the SDGs.}

DAC providers play a role in SSA infrastructure finance that cannot be easily filled by other actors. The specialisation in water and in low-income countries, where the infrastructure deficit is the most urgent, remain core areas of the DAC, and financing from the DAC is critical for countries in West and Central Africa.

Where DAC providers are engaging in destinations dominated by other actors (such as the energy sector and middle-income countries), they can enhance efficiency. For example, while Chinese providers may have the advantage of expedient processes, DAC providers could compete on the basis of quality as well as transparent and more concessional lending terms. This is especially important in the case of middleincome countries that need to navigate an increasingly complex financing landscape, and gain access to new resources with unfamiliar financing terms.

DAC providers can actively engage in co-financing and other forms of engagement with other actors including multilateral organisations, SSA governments, and Chinese entities. This would allow for synergies that leverage the different strengths of the respective actors. Moreover, concessional funds from DAC providers can be more actively used in a way to catalyse private investments, for example through blended finance transactions.

OECD data on private finance mobilised by official development finance interventions show indeed that "economic infrastructure" (including energy, transport etc) is the most targeted sector. However water and sanitation is among the least targeted. Recent work by the OECD highlights how blended finance shows promise to scale up investment in the water and sanitation sector. It shows that a range of blended finance instruments have been increasingly used, in particular guarantees and technical assistance (OECD, 2019[43]).

While the long-term benefits of economically, socially and environmentally sustainable infrastructure are clear, SSA governments, who are faced with scarce funding availability, low capacity and vast immediate infrastructure needs, may struggle to prioritise sustainability considerations. A continued presence of DAC 
members can help to align government incentives with sustainability objectives, for example by setting appropriate public sector and procurement requirements in their investments.

The DAC can strengthen efforts to promote principles and best practices on project preparation and prioritisation, while providing concessional funding for their implementation and adoption. One example are the G20 Principles for the Infrastructure Project Preparation Phase, which are based on the UK's Five Case ${ }^{10}$ Model for Project Preparation and were adopted in 2018.

In addition, DAC providers can strengthen support for upstream measures such as policy and regulatory reforms that incentivise and promote the integration of environmental and social sustainability aspects in the design and implementation of infrastructure investments. For instance, the Public-Private Infrastructure Advisory Facility (PPIAF) within the World Bank Group is a multi-donor trust fund that includes DAC donors and is aimed at improving the institutional and legal enabling environment for private sector participation infrastructure. SSA countries represent $50 \%$ of PPIAF's portfolio.

If DAC providers were to neglect infrastructure development, notably in SSA, it could not only lead to a loss of relevance but could also worsen debt sustainability problems.

With reduced access to concessional sources of finance for infrastructure investments, SSA countries will increasingly rely on more expensive financing such as capital market debt.

Moreover, the absence of alternative sources of finance will reduce their leverage in negotiating the terms of the financing from other providers. Anecdotal evidence suggests that countries restructuring loans from China could negotiate more lenient terms if they had access to a diversified creditor base (Kratz, Feng and Wright, 2019 $\left.{ }_{[3]}\right)$. More active DAC engagement in infrastructure finance in SSA can also help to promote and strengthen common frameworks and mechanisms for debt co-ordination such as the Paris Club.

However, given the scarcity of development finance resources, it should be used in a way to complement other sources of finance including private sector resources. The involvement of the private sector is also important because it can enhance the efficiency and economic viability of infrastructure projects.

\subsection{What the Development Assistance Committee can do}

\section{Building on core strengths and comparative advantages}

In light of the effect of infrastructure on poverty and inequality reduction and the interlinkages with the SDGs, there is a strong rationale for continuous engagement in infrastructure. To ensure the greatest possible alignment with the development priorities of DAC providers, programmes with an emphasis on women, youth and the poor can be prioritised. Their access to the infrastructure as well as opportunities for employment should be critical considerations in the design and implementation of the projects.

- DAC providers can play an especially strong role in promoting climate-resilient infrastructure. Climate-resilient infrastructure has the potential to improve the reliability of service provision, increase asset life and protect asset returns (OECD, 2018[44]). Sharing experience and transferring knowledge in planning, designing, mobilising finances and operating climate-resilient infrastructure, DAC members can complement and strengthen their efforts in fighting climate change and its impacts at home.

- Groups of countries and sub-sectors, in which DAC providers have a comparative advantage, need continued and targeted support. This includes low-income countries and

\footnotetext{
10 The Five Case Model is the approach for developing business cases recommended by HM Treasury, the Welsh Government and the UK Office of Government Commerce. The five cases are the strategic case, economic case, commercial case, financial case and management case.
} 
the water sub-sector, as they still experience difficulties in accessing alternative sources of finance.

- DAC providers can also support investment that build on recipient countries' core strengths and comparative advantages, which includes investments that contribute to valueaddition to domestically produced raw materials.

- DAC providers can champion and support politically less favourable projects, which nevertheless have the potential for high economic returns. Furthermore, by insisting on the sustainability of their investments, DAC members can contribute to a mind-shift of policy makers in SSA countries. As a result, more importance would be attached to maintenance and infrastructure projects would be seen in a more holistic way (comprising construction but also maintenance and operations.

- Shifting support towards infrastructure maintenance can have considerable development impact. While donor countries prioritise rehabilitation and new construction, maintenance often remains the responsibility of domestic governments. Better ensuring and including costs of maintenance in infrastructure projects financed by DAC donors can significantly lift the fiscal burden entailed by infrastructure investments.

This is especially important as maintenance is often less "visible" than new projects, which makes them less politically appealing for domestic politicians. Those political economy constraints are less pressing for external donors, which could for example set aside maintenance over the lifetime of projects, or dedicate a funded facility for this purpose to implement maintenance projects in Africa. Often, the reason for poor maintenance of infrastructure is the lack of human resources and technical expertise. DAC providers can provide targeted technical cooperation and capacity building to properly operate and maintain the infrastructure.

\section{Complementing infrastructure finance with support for domestic resource mobilisation}

To ensure that continued infrastructure investment is well-managed and does not strain the public budget, support for greater fiscal resilience in Sub-Saharan African countries needs further strengthening.

- In particular, support for domestic resource mobilisation can be enhanced. The international development community widely recognises the importance of support for domestic resource mobilisation, as manifested in the launch of the Addis Tax Initiative (ATI) in 2015, under which a number of donor countries committed collectively to double their DRM-related technical cooperation support by 2020. As a result, DRM support from member countries of the ATI rose from USD 61 million in 2014 to USD 358 million in 2016.

However, half of this support is benefitting only seven countries, three of which are in sub-Saharan Africa (Mozambique, Somalia, Tanzania) (Watts, 2018[22]). In light of the considerable tax gap of countries in sub-Saharan Africa, however, it is necessary to continue to scale up support to domestic resource mobilisation to effectively improve domestic tax systems in the region.

Beyond domestic resource mobilisation, DAC providers could enhance existing mechanisms for local currency debt facilities. External borrowing comes with risks (such as the mismatch between foreign currency-denominated debt obligations and the earning capacity related to a project, which was mentioned in Part 3) which can be transferred to the donor by removing the currency risk. This implies to revise financial risk management and offer new financial tools.

Investing in better quality public spending and debt management to minimise debt sustainability risks

- The international development community including members of the DAC increasingly promotes quality and governance aspects of infrastructure investments. Often these aspects 
are embedded in frameworks to strengthen and improve public financial management. In the mid to late 2000s, public investment management has become a critical agenda item within the context of public financial management reforms.

There is a wealth of tools offered by international organisations. The World Bank published the Diagnostic Framework for Public Investment Management (DF-PIM) in 2010. The International Monetary Fund (IMF) then introduced the Public Investment Management Assessment (PIMA) in 2015, and updated it in 2018 based on a series of PIMA assessments.

- Rather than duplicating existing efforts, DAC providers can complement and strengthen them. Moreover, DAC providers can focus on areas, which other initiatives do not cover in sufficient depth. For example, some review of current PIM support concluded that while there is an emphasis on high-level reforms, technical assistance for downstream capacities such as project selection and management can be strengthened. For privately funded infrastructure, support could be channelled to regulators and agencies who manage contracts with the private sector.

- In parallel, DAC providers can continue and build on existing efforts to incentivise public investment efficiency in SSA by allocating more infrastructure finance to countries with better results. DAC providers can also encourage and promote transparency, for example by insisting on the use of internationally competitive procurement processes.

- Moreover, DAC donors can provide technical and assistance and capacity building related to public debt management, supporting developing countries gain access to certain funds (e.g. climate finance), identify best partners and instruments, and negotiate the best terms and conditions with them. For example, the IMF and World Bank recently updated the Public-Private Partnership Fiscal Risk Assessment Model (PFRAM) tool to help governments identify, allocate, manage and price fiscal risks involved in public-private partnerships.

- DAC donors can also provide support for knowledge-sharing and mutual learning platforms for SSA countries, in which they can gather and exchange their information and experience of negotiating, managing and restructuring debt with different types of lenders.

\section{Collaborating with key partners within and outside of OECD}

Better and more systematic co-ordination with partners within and outside of the OECD is necessary to ensure that the DAC's response is in line with international efforts. While there is a growing number of international initiatives to mitigate debt sustainability concerns (Box 4.1), the DAC currently lacks mechanisms to systematically monitor and contribute to these frameworks.

- There may be a need for a dedicated work-stream within the DAC to follow up on debt trends and on developments in the international development and financial architecture, which explores implications on development assistance extended by DAC members and others as well as possible ways to align their lending patterns.

- The DAC can support standard-setting related to infrastructure finance, e.g. through involvement in the above-mentioned OECD's Sustainable Infrastructure Policy Initiative, which is led by the Directorate for Financial and Enterprise Affairs. The DAC can also encourage other providers of development cooperation including China, to adhere more closely to international standards and practices, to improve transparency and accountability in the development cooperation globally.

- The DAC can promote data transparency and accountability related to development finance provided to SSA countries, which will help to better monitor and manage debt levels.

- In light of the close link between the quality of public investment and debt sustainability, there is a need to strengthen quality aspects in development finance. For example, the DAC 
can also leverage the expertise and networks of other directorates within OECD such as the Directorate for Public Governance to conduct joint analyses and launch joint initiatives.

- The Development Centre (DEV), in co-operation with the African Centre for Economic Transformation (ACET), have recently launched a new work-stream on infrastructure and skills development, which is aims to identify areas for simplifying processes for funding and implementing infrastructure projects in Africa, while meeting the quality challenge at the same time. Through collaborative work, the DAC can feed into this new workstream, with a particular focus on what DAC providers can do in ensuring the effective delivery of quality infrastructure.

\section{Box 4.1. Recent initiatives on debt sustainability}

- OECD Recommendation on Sustainable Lending Practices and Officially Supported Export Credits (2018) http://www.oecd.org/officialdocuments/publicdisplaydocumentpdf/?doclanguage=en\&cote=tad/ecg(2008)1

- G20 Operational Guidelines for sustainable lending (2017) https://www.bundesfinanzministerium.de/Content/EN/Standardartikel/Topics/world/G7-G20/G20Documents/g20-operational-guidelines-for-sustainable-financing.pdf? blob=publicationFile \&V=1

- G20 Operational Guidelines for Sustainable Financing-Diagnostic Tool

- $\quad$ https://www.imf.org/external/np/g20/pdf/2019/111519.pdf

- IMF-World Bank Multipronged Approach to address debt vulnerabilities in low-income and emerging market economies

- $\quad$ https://www.devcommittee.org/sites/www.devcommittee.org/files/download/Documents/2018-09/DC20180011\%20Debt\%20Vulnerabilities.pdf

- Institute of International Finance (IIF) Principles for Debt Transparency (2019) https://www.mof.go.jp/english/international policy/convention/g20/annex5 3.pdf

- China's Debt Sustainability Framework for Participating Countries of the BRI http://m.mof.gov.cn/czxw/201904/P020190425513990982189.pdf

\section{Strengthen evidence-based analysis on infrastructure finance and debt sustainability}

Finally, building on the analysis provided here, the DAC can continue and deepen research efforts to inform members' infrastructure financing strategy in and outside of sub-Saharan Africa. This can include deep dives into individual countries and sub-sectors, with more granular information about specific contexts.

The following questions, with an emphasis on the role of OECD/DAC to help address the challenges involved, can guide future work:

- How do the different approaches of DAC and non-DAC providers impact on the quality of infrastructure across economic, environmental and social dimensions? What are the strengths and weaknesses of DAC and non-DAC providers, respectively?

- How can debt sustainability considerations be reflected in an infrastructure project cycle and financing framework to recipient countries?

- Are there best practice examples of quality infrastructure finance that maximise development impacts as well as minimise debt sustainability risks? If so, how can DAC providers replicate them on the ground?

- How can recipient countries best leverage the presence of different providers of infrastructure finance? How can DAC providers support them to get favourable conditions and more transparency? 


\section{References}

Abiad, A., M. Debuque-Gonzales and A. Sy (2017), The role and impact of infrastructure in middleincome countries: Anything special?, ADB, Manila, https://www.adb.org/publications/role-impact-infrastructure-middle-income-countries.

AidData (2017), "Global Chinese Official Finance Dataset, Version 1.0", https://www.aiddata.org/data/chinese-global-official-finance-dataset.

Barhoumi, K. et al. (2018), Public Investment Efficiency in Sub-Saharan African Countries, IMF, Washington D.C., https://www.imf.org/en/Publications/Departmental-Papers-PolicyPapers/Issues/2018/07/06/Public-Investment-Efficiency-in-Sub-Saharan-African-Countries45953.

Battaile, B., F. Hernández and V. Norambuena (2015), Debt sustainability in sub-Saharan Africa: Unraveling country-specific risks, World Bank, Washington D.C., http://documents.worldbank.org/curated/en/443061468197407446/Debt-sustainability-in-SubSaharan-Africa-unraveling-country-specific-risks.

Briceño-Garmendia, C., K. Smits and V. Foster (2008), Financing public infrastructure in SubSaharan Africa: Patterns and emerging issues, World Bank, Washington D.C., http://documents.worldbank.org/curated/en/936101468211804244/pdf/718150WP0v10P10Fis cal0costs0maintxt.pdf.

Buffie, E. et al. (2012), Public Investment, Growth and Debt Sustainability: Putting Together the Pieces, IMF, Washington D.C., https://www.imf.org/external/pubs/ft/wp/2012/wp12144.pdf.

Calderón, C., C. Cantú and P. Chuhan-Pole (2018), Infrastructure Development in Sub-Saharan Africa, World Bank, Washington D.C., http://documents.worldbank.org/curated/en/866331525265592425/pdf/WPS8425.pdf.

Coulibaly, B., D. Gandhi and L. Senbet (2019), Is sub-Saharan Africa facing another systemic sovereign debt crisis?, Brookings, Washington D.C., https://www.brookings.edu/wpcontent/uploads/2019/04/africa sovereign debt sustainability.pdf.

Dinkelman, T. (2011), "The Effects of Rural Electrification on Employment: New Evidence from South Africa", American Economic Review, Vol. 101, pp. 3078-3108.

Edinger, H. and J. Labuschagne (2019), If you want to prosper, consider building roads: China's role in African infrastructure and capital projects, Deloitte University EMEA CVBA, https://www2.deloitte.com/us/en/insights/industry/public-sector/china-investment-africainfrastructure-development.html. 
Hallegatte, S., J. Rentschler and J. Rozenberg (2019), Lifelines : The Resilient Infrastructure Opportunity. Sustainable Infrastructure, World Bank, Washington D.C., https://openknowledge.worldbank.org/handle/10986/31805.

Hjort, J. and J. Poulsen (2019), "The Arrival of Fast Internet and Employment in Africa", American Economic Review, Vol. 109/3, pp. 1032-79, http://dx.doi.org/DOl: 10.1257/aer.20161385.

Horn, S., C. Reinhart and C. Trebesch (2019), "China's overseas lending”, No. 2132, Keil Institute for the World Economy, https://www.ifw-kiel.de/fileadmin/Dateiverwaltung/lfWPublications/Christoph Trebesch/KWP 2132.pdf.

ICA (2019), "Financing Trends", https://www.icafrica.org/en/topics-programmes/keyachievements-in-the-financing-of-african-infrastructure-in-2018/.

IMF (2020), "World Economic Outlook Database", https://www.imf.org/external/pubs/ft/weo/2020/01/weodata/index.aspx.

IMF (2019), Debt Relief Under the Heavily Indebted Poor Countries (HIPC) Initiative, IMF, Washington D.C., https://www.imf.org/en/About/Factsheets/Sheets/2016/08/01/16/11/DebtRelief-Under-the-Heavily-Indebted-Poor-Countries-Initiative.

IMF (2018), Regional Economic Outlook: Domestic Revenue Mobilization and Private Investment, IMF, Washington D.C., https://www.imf.org/en/Publications/REO/SSA/Issues/2018/04/30/sreo0518.

IMF (2017), "Investment and Capital Stock Dataset", https://www.imf.org/external/np/fad/publicinvestment/\#5.

IMF (2017-2019), "Debt Sustainability Analysis: Low Income Countries", https://www.imf.org/external/pubs/tt/dsa/lic.aspx.

IMF/WB (2020), The Evolution of Public Debt Vulnerabilities In Lower Income Economies, IMF, Washington D.C., https://www.imf.org/en/Publications/Policy-Papers/lssues/2020/02/05/TheEvolution-of-Public-Debt-Vulnerabilities-In-Lower-Income-Economies-49018.

IMF/WB (2019), Heavily Indebted Poor Countries (HIPC) Initiative and Multilateral Debt Relief Initiative (MDRI)—Statistical Update, https://www.imf.org/en/Publications/PolicyPapers/Issues/2019/08/06/Heavily-Indebted-Poor-Countries-HIPC-Initiative-and-MultilateralDebt-Relief-Initiative-MDRI-48566.

ITU (2019), "World Telecommunication/ICT Indicators Database", https://www.itu.int/en/ITUD/Statistics/Pages/stat/default.aspx.

Izquierdo, A. et al. (2019), Is the Public Investment Multiplier Higher in Developing Countries? An Empirical Exploration, IMF, Washington D.C., https://www.imf.org/en/Publications/WP/Issues/2019/12/20/Is-the-Public-InvestmentMultiplier-Higher-in-Developing-Countries-An-Empirical-Exploration-48836.

Kratz, A., A. Feng and L. Wright (2019), New Data on the "Debt Trap" Question, Rhodium Group, https://rhg.com/research/new-data-on-the-debt-trap-question/. 
Mecagni, M. et al. (2014), Issuing international sovereign bonds: Opportunities and challenges for Sub-Saharan Africa, IMF, Washington D.C., https://translate.google.com/translate?hl=ko\&sl=en\&u=https://www.imf.org/ /media/external/p ubs/ft/dp/2014/afr1402.ashx\&prev=search.

Morris, S., B. Parks and A. Gardner (2020), Chinese and World Bank Lending Terms: A Systematic Comparison Across 157 Countries and 15 Years, Center for Global Development, Washington D.C., https://www.cgdev.org/sites/default/files/chinese-and-world-bank-lendingterms-systematic-comparison.pdf.

Mustapha, S. and A. Prizzon (2018), Africa's rising debt: How to avoid a new crisis, ODI, https://www.odi.org/sites/odi.org.uk/files/resource-documents/12491.pdf.

OECD (2020), A "debt standstill" for the poorest countries: How much is at stake?, https://www.oecd.org/coronavirus/policy-responses/a-debt-standstill-for-the-poorestcountries-how-much-is-at-stake-462eabd8/.

OECD (2019), “Creditor Reporting System”, https://stats.oecd.org/Index.aspx?DataSetCode=crs.

OECD (2019), Making Blended Finance Work for Water and Sanitation: Unlocking Commercial Finance for SDG 6, OECD Studies on Water, OECD Publishing, Paris, https://doi.org/10.1787/5efc8950-en.

OECD (2019), Sustainable Infrastructure Policy Initiative, OECD Publishing, Paris, http://www.oecd.org/finance/Sustainable-Infrastructure-Policy-Initiative.pdf.

OECD (2018), Climate-resilient infrastructure, OECD Publishing, Paris, https://doi.org/10.1787/4fdf9eaf-en.

OECD (2014), OECD Foreign Bribery Report: An Analysis of the Crime of Bribery of Foreign Public Officials, OECD Publishing, Paris, https://doi.org/10.1787/9789264226616-en.

OECD/ATAF/AUC (2019), Revenue Statistics in Africa 2019: 1990-2017, OECD Publishing, Paris, https://dx.doi.org/10.1787/5daa24c1-en-fr.

Rozenberg, J. and M. Fay (2019), Beyond the Gap : How Countries Can Afford the Infrastructure They Need while Protecting the Planet. Sustainable Infrastructure, World Bank, Washington DC, https://openknowledge.worldbank.org/handle/10986/31291 License: CC BY 3.0 IGO.

Stansbury, N. (2005), Exposing the foundations of corruption in construction, https://www.transparency.org/whatwedo/publication/global corruption report 2005 corruptio $\underline{\mathrm{n} \text { in construction and post conflict. }}$

Thacker, S. et al. (2019), "Infrastructure for sustainable development", Nature Sustainability, Vol. 2, pp. 324-331, https://doi.org/10.1038/s41893-019-0256-8.

Velde, D. (2014), Mobilisation and effective use of domestic resources for a transformative post2015 agenda, Overseas Development Institute, London, https://www.odi.org/sites/odi.org.uk/files/odi-assets/publications-opinion-files/9030.pdf.

Watts, R. (2018), ODA for domestic revenue mobilization: progress, prospects and opportunities for effective support, Development Initiatives, Bristol, http://devinit.org/wpcontent/uploads/2018/07/ODA-for-domestic-revenue-mobilisation.pdf. 
WEF (2017-2018), "Global Competitiveness Index", http://reports.weforum.org/pdf/gci-20172018-scorecard/WEF GCI 20172018 Scorecard EOSQ057.pdf.

WHO (2020), Global Health Observatory (GHO) data: Under-five mortality, World Health Organization, Geneva, https://www.who.int/gho/child health/mortality/mortality under five text/en/.

WHO (2019), Facts sheets - HIV/AIDS, World Health Organisation, Geneva, https://www.who.int/news-room/fact-sheets/detail/hiv-aids.

World Bank (2020), World Development Indicators (database), https://datacatalog.worldbank.org/dataset/world-development-indicators.

World Bank (2019), "Private Participation in Infrastructure Projects Database", https://ppi.worldbank.org/en/ppidata.

World Bank (2018), "Country Policy and Institutional Assessment", https://databank.worldbank.org/reports.aspx?source=country-policy-and-institutionalassessment. 


\section{Annex A. Methodological annex}

\section{A.1 Data sources and limitations}

The analysis in this paper is based on data on DAC members' and multilateral official flows (official development assistance (ODA) and other official flows (OOF) based on the OECD Creditor Reporting System (CRS), as well as financing provided by Chinese entities, as estimated by AidData's Global Chinese Official Finance dataset. DAC and Chinese flows cannot be directly compared, as the latter includes flows that would not necessarily be categorised as ODA nor OOF in the CRS. (IMF/WB, $\left.2020_{[45]}\right)$ Moreover, AidData provides estimates based on financing commitment, while the CRS data used here are based on disbursements. Combining the data, however, serves the purpose of the analysis to provide insights into different emerging patterns and the overall direction of trends.

Data from the World Bank's Private Participation in Infrastructure have been included to account for financing channelled through public-private partnerships. Since these data do not differentiate between the public and private components of the financing involved in projects, aggregating these data is subject to double counting, as some of the official development finance can be directed towards the investments captured in the PPI database. Self-standing private finance for infrastructure investments are excluded from this analysis due to limited data availability. ${ }^{11}$

Combining data from different sources, which have been collected using different methodologies, limiting the comparability across sources. The OECD Creditor Reporting System (CRS) was used for data on financing from multilateral and bilateral DAC and DAC-reporting providers, while the data on financing from Chinese entities comes from AidData's Global Chinese Official Finance Dataset, 2000-2014, Version 1.0.

AidData provides the most comprehensive source of information on Chinese development finance comes, which is collected through news report and experts contributions. However, due to the nature of how the data are collected, the datacan have significant gaps for non-disclosed projects. Moreover, the data are only available from 2000 to 2014, which considerably limits the timeliness of analysis.

Data from the World Bank's Private Participation in Infrastructure (PPI) have also been included to account for financing channelled through public-private partnerships. Since these data do not differentiate between the public and private components of the financing involved in projects, aggregating these data is subject to double counting, as some of the official flows can be directed towards the investments captured in the PPI database.

However, the analysis based on this kind of granular data can provide meaningful, albeit tentative, indication of the sectoral and country destinations of different sources of finance, which can add some insight into what the role of the Development Assistance Committee is. .

\footnotetext{
${ }^{11}$ According to the ICA, these investments amounted to USD 9.5 billion for the whole region of Africa including northern Africa. (ICA, 2019 [13]).
} 


\section{A.2 Methodological note for construction of index in Figure 1.2 and Figure 1.3}

- Table A.1 below summarises all the metrics used for each dimension and the corresponding source.

- All indicators are weighted by either population size or land area.

- Given issues of data availability - i.e. not all indicators are available for the same years - we construct this index using the latest available data (excluding all observations for which the latest year is before 2010).

- For normalisation, we choose to employ the ranking normalisation technique, where the best performer for each indicator is given a score of 100 and the rest are normalised accordingly with respect the best performer (i.e. for each indicator, divide the value for all countries with the best performer value and multiply by 100 ).

- To aggregate for each dimension, we take a simple average of the normalised value of all the indicators that fall under that dimension. To aggregate across all dimensions, we take simple average of the quality, quantity, and access index figure. If there is a country for which one dimension is entirely missing, it is dropped from the sample.

Table A.1. Summary of indicators by dimension and subsector

\begin{tabular}{|c|c|c|c|c|}
\hline Dimension & Subsector & Indicator & Source & Notes \\
\hline Quantity & Telecommunications & $\begin{array}{c}\text { Fixed } \\
\text { telephone } \\
\text { subscriptions } \\
\text { (weighted by } \\
\text { population) }\end{array}$ & $\begin{array}{c}\text { International Telecommunications Union's World } \\
\text { Telecommunication/ICT Indicators (https://www.itu.int/en/ITU- } \\
\text { D/Statistics/Pages/stat/default.aspx) }\end{array}$ & \\
\hline Quantity & Telecommunications & $\begin{array}{c}\text { Mobile } \\
\text { telephone } \\
\text { subscriptions } \\
\text { (weighted by } \\
\text { population) }\end{array}$ & $\begin{array}{c}\text { International Telecommunications Union's World } \\
\text { Telecommunication/ICT Indicators (https://www.itu.int/en/ITU- } \\
\text { D/Statistics/Pages/stat/default.aspx) }\end{array}$ & \\
\hline Quantity & Telecommunications & $\begin{array}{l}\text { Percent of } \\
\text { individuals } \\
\text { using the } \\
\text { internet }\end{array}$ & $\begin{array}{c}\text { International Telecommunications Union's World } \\
\text { Telecommunication/ICT Indicators (https://www.itu.int/en/ITU- } \\
\text { D/Statistics/Pages/stat/default.aspx) }\end{array}$ & \\
\hline Quantity & Telecommunications & $\begin{array}{c}\text { Fixed } \\
\text { broadband: } \\
\text { number of } \\
\text { subscriptions } \\
\text { (weighted by } \\
\text { population) }\end{array}$ & $\begin{array}{c}\text { International Telecommunications Union's World } \\
\text { Telecommunication/ICT Indicators (https://www.itu.int/en//TU- } \\
\text { D/Statistics/Pages/stat/default.aspx) }\end{array}$ & \\
\hline Quantity & Energy & $\begin{array}{l}\text { Electricity } \\
\text { production } \\
\text { (weighted by } \\
\text { population) }\end{array}$ & International Energy Agency & $\begin{array}{l}\text { Use } \\
\text { electricity } \\
\text { production } \\
\text { to proxy } \\
\text { for energy } \\
\text { generating } \\
\text { capacity }\end{array}$ \\
\hline Quantity & Transport & $\begin{array}{l}\text { Road length } \\
\text { weighted by } \\
\text { land area }\end{array}$ & $\begin{array}{l}\text { GRIP } 2018 \text { (https://datacatalog.worldbank.org/dataset/grip- } \\
\text { global-roads-inventory-project-2018) }\end{array}$ & \\
\hline Quantity & Transport & $\begin{array}{l}\text { Railroad } \\
\text { length } \\
\text { weighted by } \\
\text { land area }\end{array}$ & World Bank Development Indicators & \\
\hline Quality & Telecommunications & $\begin{array}{l}\text { Internet } \\
\text { bandwidth: }\end{array}$ & $\begin{array}{l}\text { International Telecommunications Union's World } \\
\text { Telecommunication/ICT Indicators ("S:IDatalSDFIWork }\end{array}$ & \\
\hline
\end{tabular}




\begin{tabular}{c|c|c|c|c}
\hline & & $\begin{array}{c}\text { bits per } \\
\text { second per } \\
\text { internet user }\end{array}$ & streams/Aid ArchitecturelSECTOR ANALYSESUINFRAlindexIRE \\
Data request.msg")
\end{tabular}

